\title{
Helicônias brasileiras: características, ocorrência e usos ${ }^{(1)}$
}

\author{
CARLOS EDUARDO FERREIRA DE CASTRO(2), CHARLESTON GONÇALVES(3), SILVIA ROCHA MOREIRA(4), \\ OTAVIO AUGUSTO FARIA(5)
}

\begin{abstract}
RESUMO
Face o constante crescimento do cultivo de helicônias no Brasil, processo que alia aumento de área cultivada com a diversificação de espécies exploradas, propôs-se, neste trabalho, apresentar aquelas que têm ocorrência natural em nosso país. Para cada espécie, foi definida a sinonímia, elaborada uma breve caracterização botânica e indicadas as regiões e ambiente de ocorrência natural. Também foram evidenciadas algumas características que as diferenciam de outras espécies do gênero e comentado seu uso como planta ornamental. São relatadas 34 espécies como de ocorrência natural do Brasil, incluindo a $H$. schumanniana Loes. e excluindo a $H$. latispatha Benth, constante em outros artigos, uma vez que no aprofundamento da revisão e consultas efetuadas em trabalhos científicos, descrição de espécies, relatos de expedições de coleta e informações pessoais de especialistas no gênero, não foi encontrado o necessário suporte para mantê-la como espécie de ocorrência natural do Brasil.
\end{abstract}

Palavras-chave: flores tropicais, flor de corte, planta nativa, Heliconiaceae.

\section{ABSTRACT \\ Brazilian heliconias: characteristics, ocurrence and uses}

Face the constant growth of the culture of heliconias in Brazil, process that unites increase of cultivated area with the diversification of explored species, in this work is related those that have natural occurrence in our country. Is boarded to each species your synonym, a brief botanical characterization, regions and enviromental conditions of natural occurrence, some characteristics that differentiate it of other species and your indications of its use as ornamental plant. Thirty-four species of natural occurrence of Brazil are characterized, including H. schumanniana Loes. and excluding H. latispatha Benth., related in previous work, a time that the deepening of the revision and consultations effected in scientific papers, description of species, stories of collection expeditions and personal information of specialists in the specie, wasn't found the necessary support to keep it as species of natural occurrence of Brazil.

Keywords: tropical flowers, cut-flower, native plant, Heliconiaceae.

\section{INTRODUÇÃO}

Originalmente incluído na família Musaceae, o gênero Heliconia, em função de suas características próprias de individualização, passou a constituir a família Heliconiaceae como único representante (NAKAI, 1941), interpretação endossada por outros autores como CRONQUIST (1981) e TOMLINSON $(1959 ; 1962)$.

Em função dos conhecimentos atuais, as diversas espécies de Heliconia podem ser subdivididas em 5 subgêneros: (1) Taeniostrobus (Kuntze) Griggs; (2) Stenochlamys Baker, com 6 secções; (3) Heliconiopsis; (4) Heliconia Griggs, com 6 secções; e (5) Griggsia, com 11 secções.

Baseados na revisão filogenética de Zingiberales, nos padrões de distribuição geográfica e na diversidade de Heliconia, foram determinadas como de ocorrência natural, no Brasil, 65 espécies, das quais provavelmente 28 são sinonímias, existindo controvérsias para outras 8 espécies (KRESS, 1990). Entretanto, em várias outras publicações, são encontradas referências que permitem relacionar aproximadamente 40 espécies de helicônias de ocorrência natural no Brasil (BARREIROS, 1970; 1971ab; 1972; 1974abc; 1980e; BURLE MARX, 1974; MELO FILHO, 1976; MELO FILHO \& SANTOS 1976, 1983, 1987ab;
SANTOS, 1978). Nos últimos anos, com base nas descrições das espécies e em revisões do gênero, foram definidas como nativas do Brasil as espécies H. episcopalis, H. bihai, H. stricta, H. spathocircinata, H. lourteigiae, H. farinosa, H. kautzkiana, H. rivularis, $H$. sampaioana, $H$. velloziana, $H$. chartaceae, $H$. juruana, $H$. pendula, $H$. acuminata, $H$. angusta, $H$. psittacorum, $H$. richardiana, $H$. aemygdiana, $H$. pseudoaemygdiana, $H$. densiflora, $H$. lasiorachis, $H$. metallica, H. subulata, H. apparicioi, H. hirsuta, H. marginata, $H$. latispatha, $H$. x rauliniana, $H$. julianii, $H$. rostrata, $H$. standley, $H$. tenebrosa, $H$. timothei e $H$. velutina, num total de 34 (CASTRO \& GRAZIANO, 1997; CASTRO et al. 2007).

O gênero Heliconia compreende plantas rizomatosas, herbáceas, perenes e de tamanho médio a grande (BELL \& TOMLINSOM, 1980). Possui um tubo semelhante a um caule, ereto, aéreo, composto pela sobreposição das bainhas das folhas chamado de pseudocaule. Cada haste ereta é composta de um pseudocaule e de folhas, geralmente terminada com uma inflorescência. O pseudocaule pode atingir vários metros de altura e tem muitas colorações e texturas. Em algumas espécies como H. pendula, o pseudocaule é recoberto por uma camada cerosa de coloração esbranquiçada. O rizoma se ramifica simpodialmente a partir

\footnotetext{
(1) Recebido em 20/04/2010 e aceito em 03/05/2011.

(2)APTA - Instituto Agronômico - Centro de Horticultura, Caixa Postal 28, Campinas, SP, CEP 13012-970. e-mail ccastro@iac.sp.gov.br;

${ }^{(3,4)}$ APTA - Polo Regional do Vale do Paraíba - UPD de Ubatuba, Rodovia Oswaldo Cruz, 5061, Ubatuba, SP, CEP 11680-000. e-mail: charleston@ apta.sp.gov.br e silviamoreira@apta.sp.gov.br

(5) Engenheiro Agrônomo, autônomo. e-mail otavio.faria@gmail.com
} 
de gemas da base do pseudocaule. O crescimento vegetativo é muito vigoroso, frequentemente dando crescimento a grandes populações monoclonais. Conforme a espécie, as plantas individuais formam touceiras ou se alastram, tendo diferentes práticas de manuseio.

\section{Descrição das espécies de ocorrência natural no Brasil}

As espécies de Heliconia de ocorrência natural no Brasil são apresentadas observando-se sua inclusão em três dos cinco subgêneros em que são subdivididas. Ocorrem no Brasil espécies incluídas nos seguintes subgêneros: (1) Heliconia Griggs; (2) Stenochlamys Baker; e (3) Griggsia L. Anderss.

\section{Subgênero Heliconia:}

\subsection{Sect. Episcopales (Griggs) L. Anderss.}

\subsubsection{H. episcopalis Vell (Figura 1).}

Sinonímias: (1) H. ferdinando-coburgii Szyszylowicz; (2) H. thyrsoidea Martius ex Petersen; (3) H. biflora Eichler ex Petersen (CASTRO et al. 2007).

Planta de hábito musóide, com 1,5 a 4,0 metros de altura. Apresenta inflorescência achatada, capitada, ereta, de 7,5 a 30,0 cm de comprimento, com raque reta, de coloração esverdeada e levemente pubérula. As brácteas, em número de 7 a 40 por inflorescência, são densamente sobrepostas e distribuem-se em um mesmo plano. Estão inseridas em um ângulo de 15 a $40^{\circ}$ em relação ao eixo da inflorescência, têm coloração vermelha a alaranjada com ápices amarelo avermelhados em direção a base. Apresentam a marcante característica de serem caducas no transcorrer da maturidade da inflorescência. As flores retas a levemente curvadas, 1 a 3 por bráctea, são brancas ou amarelas a alaranjadas com nuances de verde em direção ao ápice (SANTOS, 1978).

Ocorre naturalmente em altitudes do nível do mar a 800 metros, no norte do Estado do Rio de Janeiro, no Espírito Santo, na Bahia, em Minas Gerais, no Amazonas e em Roraima, em margens de rios, em clareiras de florestas úmidas e mesmo na vegetação secundária de florestas ou em locais pantanosos. Na região de ocorrência natural, floresce o ano todo, com pico entre setembro e fevereiro (SANTOS, 1978).

Sua distinção de outras espécies é fácil pela forma capitada da inflorescência e presença de cicatrizes no pedúnculo decorrente da queda de brácteas.

A H. episcopalis é cultivada preferencialmente a pleno sol, em locais de solo encharcado. Tem seu uso mais difundido como planta para jardim, cultivada de forma isolada ou formando maciços. Em algumas localidades, suas inflorescências são comercializadas como flor de corte.

As principais cultivares comerciais são Spear, Red Orange Spear e Yellow Spear.

\subsection{Sect. Heliconia L. Anderss.}

\subsubsection{H. bihai (L.) L. (Figura 2).}

Sinonímias: (1) H. humilis Jac.; (2) H. distans Griggs; (3) H. purpurea Griggs; (4) H. rutila Griggs; (5) H. schaeferiana Rodriguez; (6) H. jacquinii Lane ex Barreiros; (7) H. caribaea auct. non Lam (CASTRO et al. 2007).
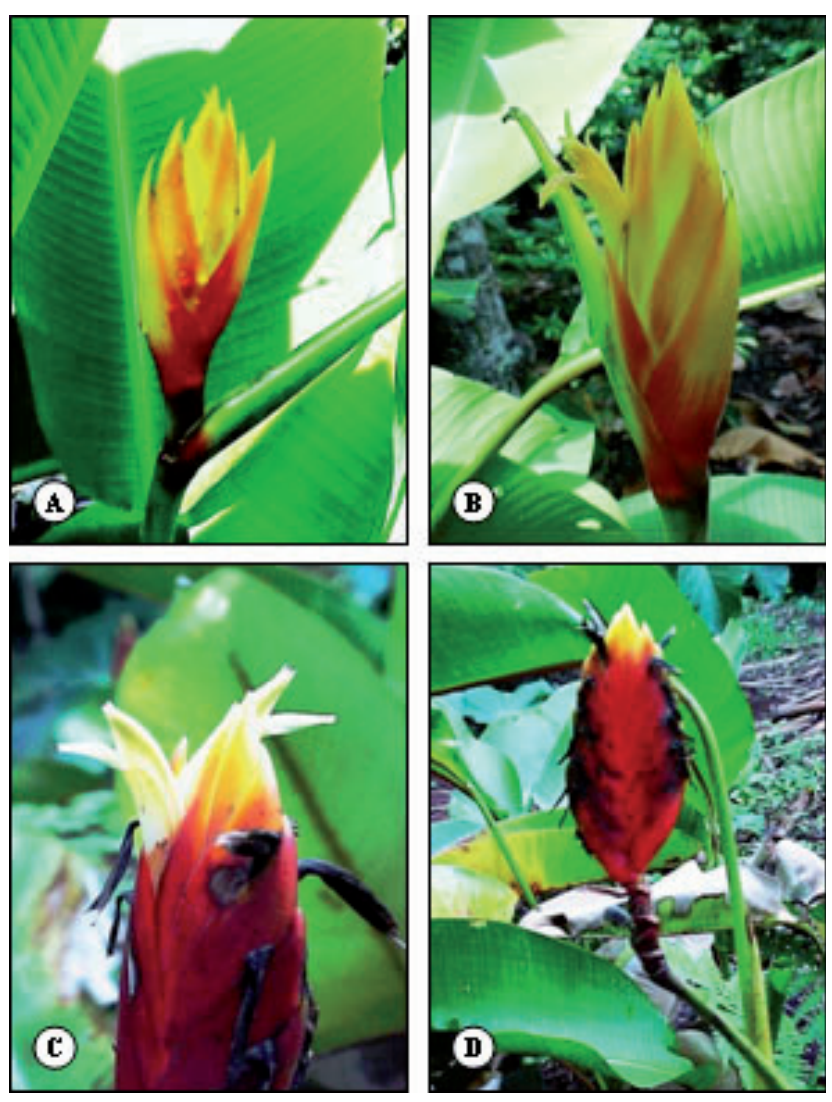

Figura 1. Heliconia episcopalis Vell.: a e b) cultivar Spear; c) inflorescência com secamento das flores; d) inflorescência com cicatrizes na raque decorrente da queda de brácteas.

Figure 1. Heliconia episcopalis Vell.: a and b) cultivar Spear; c) inflorescence flower burning; d) inflorescence with rachis scars due bract's fall.

Obs. ANDERSSON (1981) também considera a H. aurea Rodriguez como sinonímia.

Planta de hábito musoide, com 2,0 a 5,0 metros de altura. Essa espécie é glabra e as hastes, pecíolo e face inferior das folhas e brácteas inferiores da inflorescência apresentam uma camada cerosa esbranquiçada irregularmente distribuída. A inflorescência é ereta, de 30,0 a 60,0 cm de comprimento, conforme a variedade, com raque quase reta ou mais ou menos sinuosa, geralmente vermelha e algumas vezes amarelo-esverdeada. As brácteas persistentes, em número de 5 a 15 por inflorescência, distribuem-se geralmente em um mesmo plano, sendo rara a ocorrência em planos diversos devido à torção da raque. Estão inseridas em um ângulo de 35 a 90 em relação ao eixo da inflorescência, têm coloração vermelha com estreita margem verde a amarelo com manchas avermelhadas, embora o padrão básico seja brácteas com laterais vermelhas, quilha amarela e margem e base verdes. As flores quase retas a levemente parabólicas, 10 a 20 por bráctea, são brancas a verde claro em direção ao ápice (ANDERSSON, 1981).

Ocorre naturalmente do nível do mar a 1.500 metros no norte do país, nos Estado do Pará, Amazonas, Amapá e Roraima, em margens de rios de florestas úmidas, em clareiras e mesmo na vegetação secundária. Floresce na região de ocorrência natural entre outubro e fevereiro (ANDERSSON, 1981). 
Caracteriza-se por suas brácteas de colorações diversas na quilha e margens.

Distingue-se da $H$. stricta pela coloração menos intensa das brácteas e cor da flor, além de ser mais vigorosa.

Cultivada tanto a pleno sol como em locais levemente sombreados. O cultivo a pleno sol ocasiona, em algumas variedades cultivadas em certas regiões do país, como no litoral norte do Estado de São Paulo, a queimadura das brácteas das inflorescências e das folhas, depreciando as plantas. Plantas cultivadas em locais levemente sombreados apresentam coloração mais escura da folhagem e das brácteas das inflorescências. Em condições de sombra intensa, as plantas são menos produtivas.

As diversas variedades cultivadas de $H$. bihai constituem uma das plantas mais utilizadas como flor de corte no país, devido à sua durabilidade e fácil cultivo. Também é muito empregada em jardins, em cultivos isolados, em maciços florais, ou mesmo, em cercas vivas.

As principais cultivares comerciais são: Arawak, Balisier, Banana Split, Chocolate Dancer, Emerald Forest, Five A. M., Giant Lobster Claw, Guapa, Hatchet, Halloween, Jaded Forest, Kamehameha, Kuma Negro, Lobster Claw One, Lobster Claw Two, Nappi, Nappi Yellow, New Yellow Dancer, Peachy Pink, Purple Throat, Schaefer's Bihai, Yellow Dancer, Dwarf Áurea, Trinidad Balisier, Kaneiku, St. Vincent Yellow, St. Lucia Green, Schneana, Dwarf Grenada, Baby Bihai, Baby Arawak, Enchanted Forest, Yellow Forest, Kaneiku Negro, Tobago Yellow, Pont Casse e Lobster Claw Three.

\subsubsection{H. stricta Huber (Figura 3).}

Sinonímias: H. humilis auct. non Jacq.; H. tricolor Abalo \& Morales (CASTRO et al. 2007).

Planta de hábito musoide, com 1,5 a 4,0 metros de altura, com ou sem camada de cerosidade na face inferior das folhas. Apresenta inflorescência ereta, de 20,0 a 30,0 cm de comprimento, com raque reta ou levemente sinuosa, de coloração amarela para vermelha. As brácteas, em número de 3 a 10 por inflorescência, distribuem-se em um mesmo plano. Estão inseridas em um ângulo de 30 a $65^{\circ}$ em relação ao eixo da inflorescência, têm coloração vermelha a alaranjada nas laterais, amarela ou verde nas margens. As flores são de 10 a 35 por bráctea, brancas ou amareladas com a porção mediana verde brilhante (ANDERSSON, 1981).

Ocorre naturalmente desde o nível do mar até 1.500 metros de altitude, nos Estados do Amazonas e Acre, em florestas secundárias e primárias degradadas e úmidas, em margens de rios, beira de estradas e locais com solos encharcados. Na região de ocorrência natural, floresce de setembro a fevereiro (ANDERSSON, 1981).

Sua distinção da H. bihai é feita pelas brácteas de coloração brilhante e pela coloração das flores, que apresentam a porção apical branca ou branco-amarelada.

A H. stricta tem seu cultivo recomendado em locais levemente sombreados, sendo utilizada tanto como flor de corte como em jardins compondo maciços florais.

As principais cultivares comerciais são: Bob Wilson, Bucky, Burning Desire, Canary Yellow, Carli's Sharonii, Castanza, Cochabamba, Cooper's Sharonii, Dark Desire, Dimples, Dorado Gold, Dwarf Jamaican, Dwarf Wag, Elsie, Fire Bird, Iris, Las Cruces, Lee Moore, Royal, Olivera's
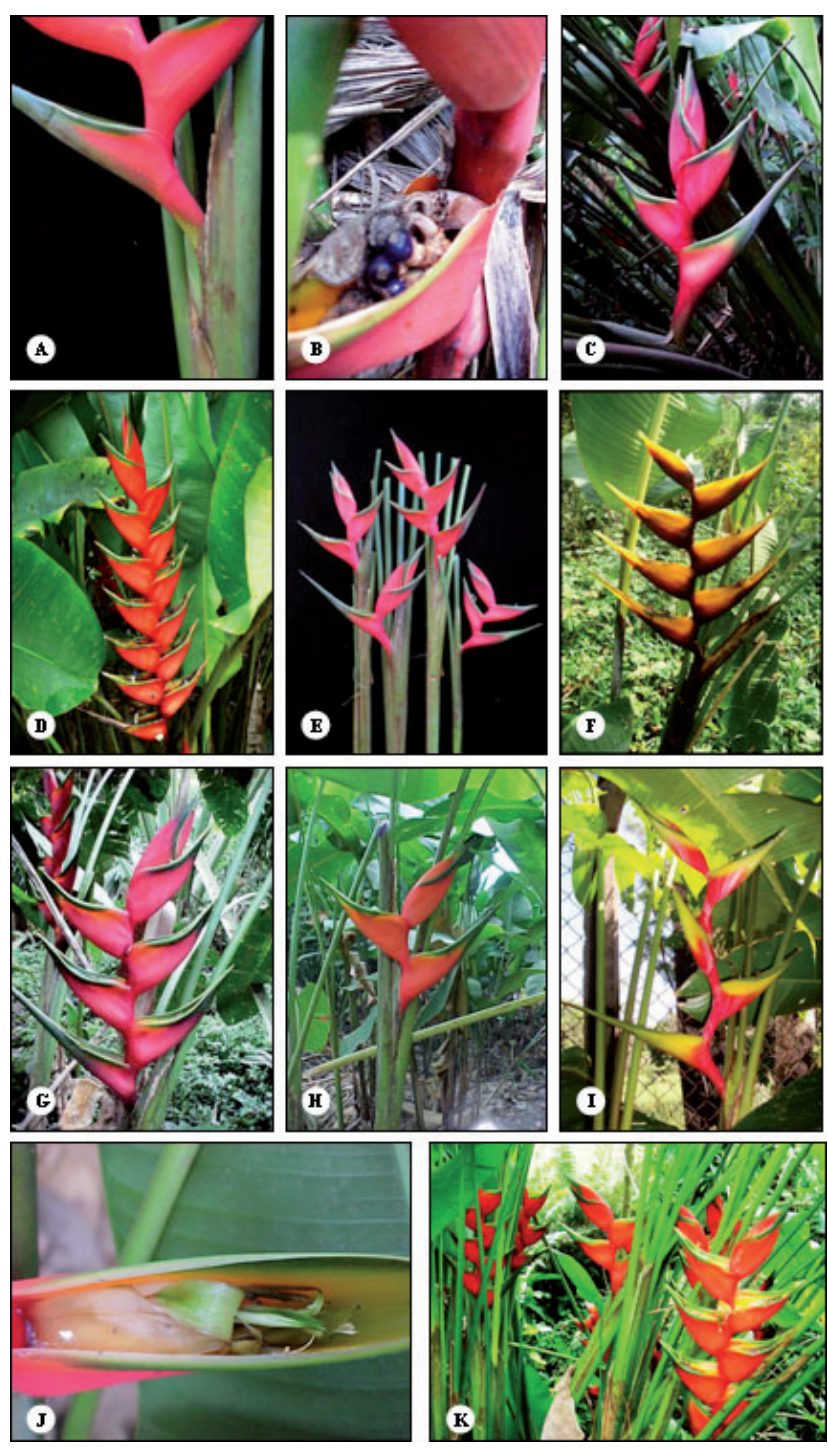

Figura 2. Heliconia bihai: a) inserção da bráctea no pseudocaule; b) frutos maduros no interior da bráctea; c) cultivar Five A.M.; d) cultivar Lobster Claw One; e) inflorescências da cultivar Five A.M.; f) cultivar Chocolate Dancer; g) cultivar Lobster Claw Two; h) cultivar Halloween; i) cultivar Nappi Yellow; j) deposição de liquido no interior da bráctea; k) produção por touceira.

Figure 2. Heliconia bihai: a) bract insertion on pseudostem; b) mature fruits inside the bracts; c) cultivar Five A.M.; d) cultivar Lobster Claw One; e) inflorescences of cultivar Five A.M.; f) cultivar Chocolate Dancer; g) cultivar Lobster Claw Two; h) cultivar Halloween; i) cultivar Nappi Yellow; j) liquid deposition inside the bracts; $k$ ) plant production.

Sharonii, Orange, Oriole Orange, Pascuita, Petite, Royal Tagami, Slash and Burn, Swish, Tagami e Jamaica.

\subsection{Sect. Tortex L. Anderss.}

\subsubsection{H. spathocircinata Aristeg. (Figura 4).}

Sinonímias: (1) H. spatho-circinada Aristeguieta; (2) $H$. linneana Lane ex Barreiros; (3) H. linneana var. flava Barreiros; (4) H. paraensis Huber ex Santos; (5) H. rollinsii Lane ex Santos (CASTRO et al. 2007). 

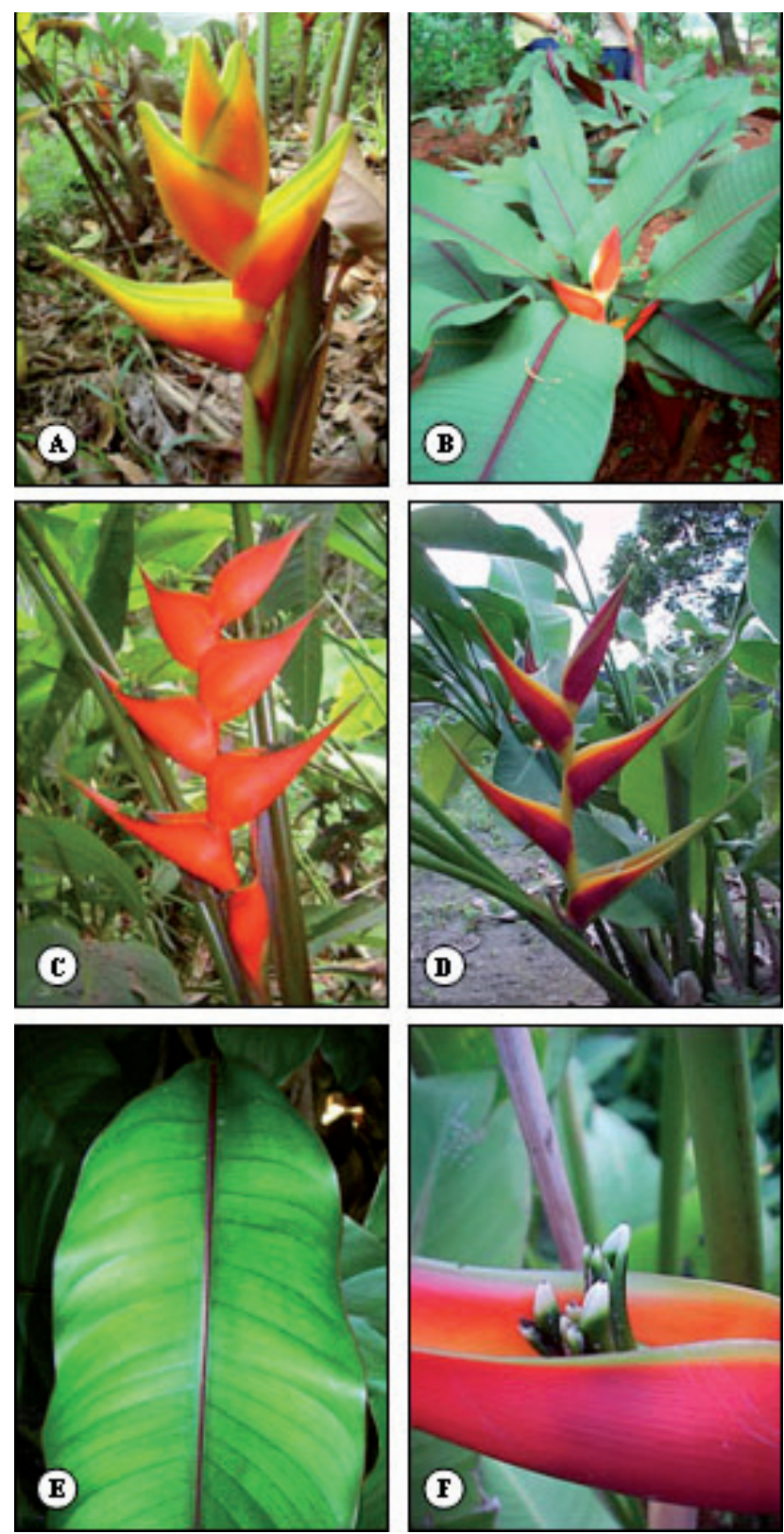

Figura 3. Heliconia stricta: a) cultivar Dorado Gold; b) Cultivar Oliveira's Sharonii; c) cultivar Las Cruces; d) cultivar Iris; e) folha da cultivar Dwarf Jamaica; f) flores bicolores no interior da bráctea.

Figure 3. Heliconia stricta: a) cultivar Dorado Gold; b) cultivar Oliveira's Sharonii; c) cultivar Las Cruces; d) cultivar Iris; e) leaves of cultivar Dwarf Jamaica; f) bicolored flowers inside the bracts.

Planta de hábito musoide, com 1,5 a 3,0 metros de altura. Apresenta inflorescência ereta, com 10,0 a 35,0 cm de comprimento, com raque sinuosa, de coloração vermelha ou amarelada e glabra ou pubérula. As brácteas persistentes, em número de 4 a 12 por inflorescência, são distribuídas em espiral. Estão inseridas em um ângulo de 55 a $90^{\circ}$ em relação ao eixo da inflorescência e têm coloração vermelha ou alaranjada, algumas vezes com margens amarelas ou verde-amareladas e com pilosidade. As flores variam de quase retas a uniformemente curvadas, de 2 a 3 por bráctea e amarelas (ARISTEGUIETA, 1961).

Ocorre naturalmente em altitudes do nível do mar a 600 metros principalmente nos Estados do Rio de Janeiro, São Paulo, Espírito Santo, Bahia, Ceará, Pará, Amapá, Amazonas, Mato Grosso e Pernambuco, em matas secundárias ou primárias, colonizando rapidamente clareiras e áreas degradadas (ARISTEGUIETA, 1961).

Na região de ocorrência natural, tem os nomes populares de caeté ou banana do mato.

É distinguida facilmente de outras espécies pelo indumento das inflorescências e por suas brácteas largas e com ápice enrolado em espiral.

Embora tenha ampla distribuição no Brasil, essa espécie não é utilizada nem como planta de jardim, nem como flor de corte. Nesse último caso, a razão de não ser utilizada se deve à sua baixa durabilidade.

\subsection{Sect. Tenebria L. Anderss.}

\subsubsection{H. lourteigiae Emygdio \& Santos (Figura 5)}

Sinonímia: H. lourtegii Emygdio \& Santos (CASTRO et al. 2007).

Planta de hábito musoide, com 0,45 a 0,80 metros de altura. Apresenta inflorescência ereta, de 10,0 a 21,0 cm de comprimento, com raque reta, esverdeada e glabra. As brácteas, em número de 3 a 6 por inflorescência, distribuem-se em um mesmo plano. Estão inseridas em um ângulo de 40 a $65^{\circ}$ em relação ao eixo da inflorescência, são glabras e têm coloração entre amarela-esbranquiçada a verde claro e a púrpura escuro internamente. As flores são parabólicas, de 2 a 3 por bráctea, brancas e róseo claras em direção ao ápice (MELLO FILHO \& SANTOS, 1977).

Ocorre naturalmente em altitudes de 300 a 800 metros, nos Estados do Amazonas e Roraima, em florestas úmidas, fechadas. Na região de ocorrência natural, floresce de outubro a março (MELLO FILHO \& SANTOS, 1977).

São reconhecidas por seu pequeno tamanho, brácteas externamente amarelo-esbranquiçadas a verde claras e púrpuras internamente, com ápice flexionado e flores tubulares brancas.

A espécie tem sido cultivada no Estado do Amazonas para uso como flor de corte. Para seu cultivo bem sucedido, devem ser providos locais bem sombreados. Deve se adaptar bem ao cultivo em vasos pela sua baixa altura e pode ser empregada em jardins formando maciços florais.

\subsubsection{H. tenebrosa Macbr. (Figura 6)}

Planta de hábito musoide, com 0,5 a 1,3 metros de altura. Apresenta inflorescência ereta com 7,0 a 23,0 cm de comprimento, com raque sinuosa, de coloração vermelha a púrpura. As brácteas, em número de 3 a 10 por inflorescência, distribuem-se em um mesmo plano. Estão inseridas em um ângulo de 40 a $70^{\circ}$ em relação ao eixo da inflorescência e têm coloração verde, algumas vezes esbranquiçadas junto à base e são púrpuras internamente. As flores são acentuadamente parabólicas, de 6 a 8 por bráctea, brancas e glabras (MACBRIDE, 1931).

Ocorre naturalmente em altitudes de 100 a 800 metros nos Estados do Amazonas e Roraima, em florestas primárias e secundárias úmidas. Na região de ocorrência natural, floresce de outubro a março (MACBRIDE, 1931).

Espécie semelhante à $H$. lourteigiae, se diferencia por ter lâminas foliares maiores e mais largas e flores com tubo 

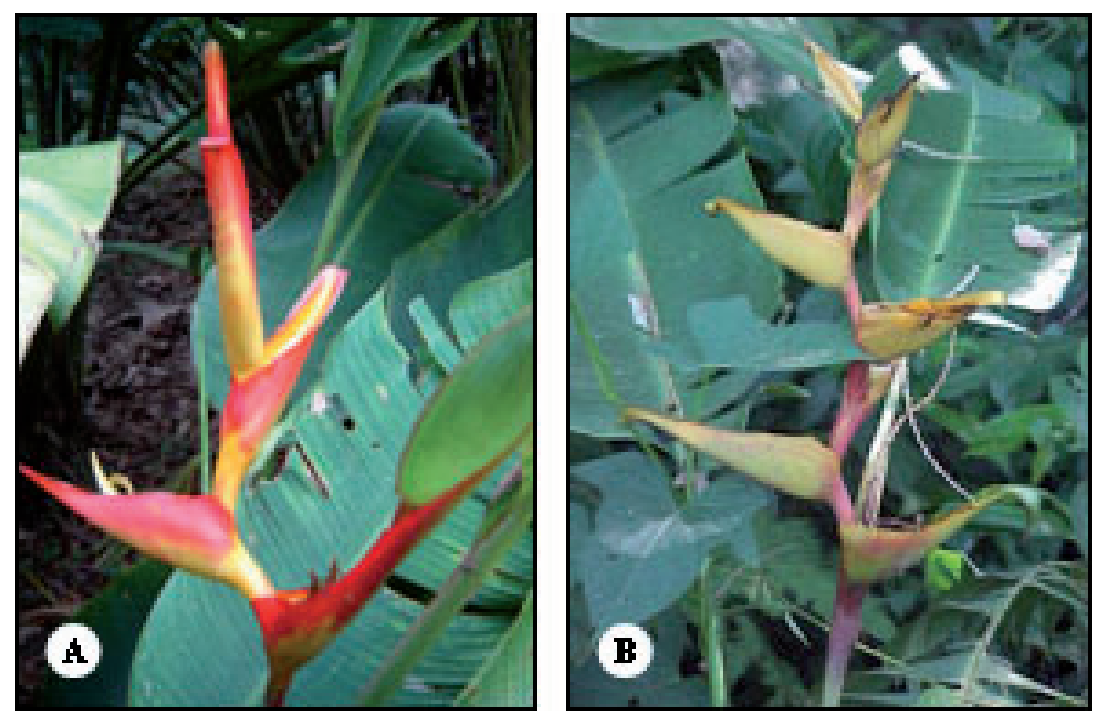

Figura 4. Heliconia spathocircinata: a e b) variação de cor de brácteas em indivíduos em população natural na região do litoral norte paulista.

Figure 4. Heliconia spathocircinata: $a$ and b) bract color variation among plants in natural population in São Paulo state north coast.

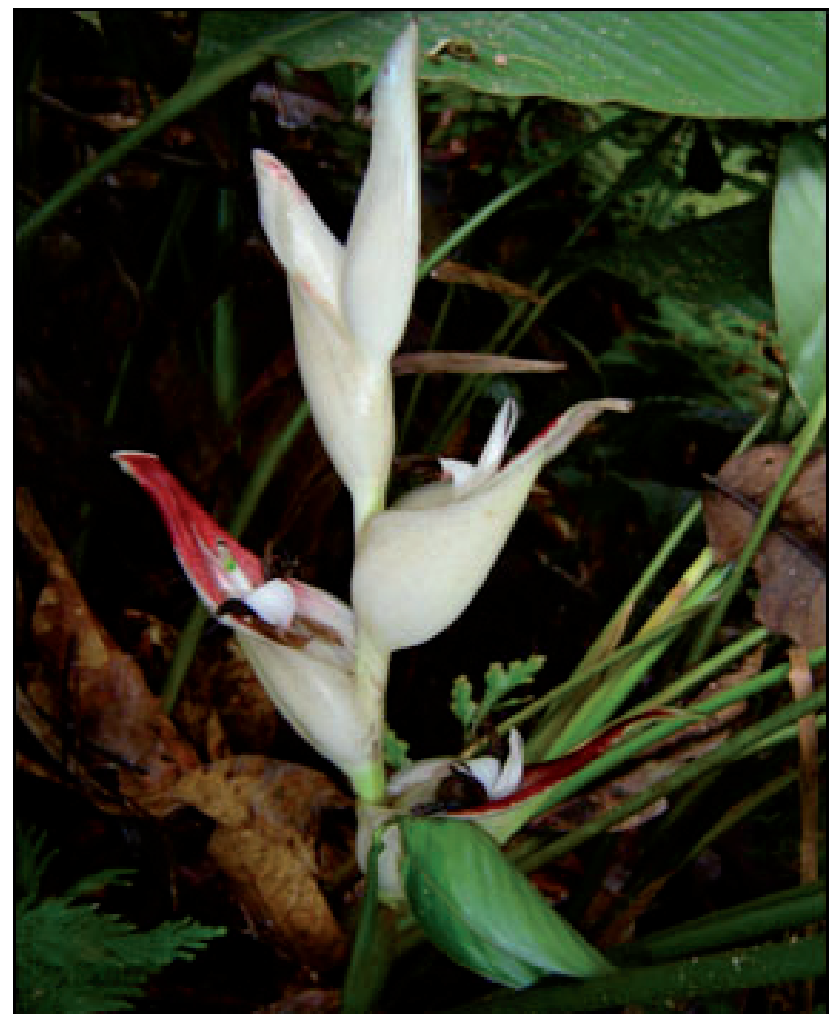

Figura 5. Heliconia lourteigiae.

Figure 5. Heliconia lourteigiae.

pequeno.

Espécie não cultivada e só conhecida nas regiões de ocorrência natural.

\subsection{Sect. Farinosae W. J. Kress}

\subsubsection{H. farinosa Raddi (Figura 7).}

Sinonímias: (1) H. braziliensis Hooker; (2) H. pulverulenta Lindley; (3) H. dealbata Loddiges ex Baker; (4) H. farinosa var. efarinosa Barreiros; (5) H. farinosa (var.

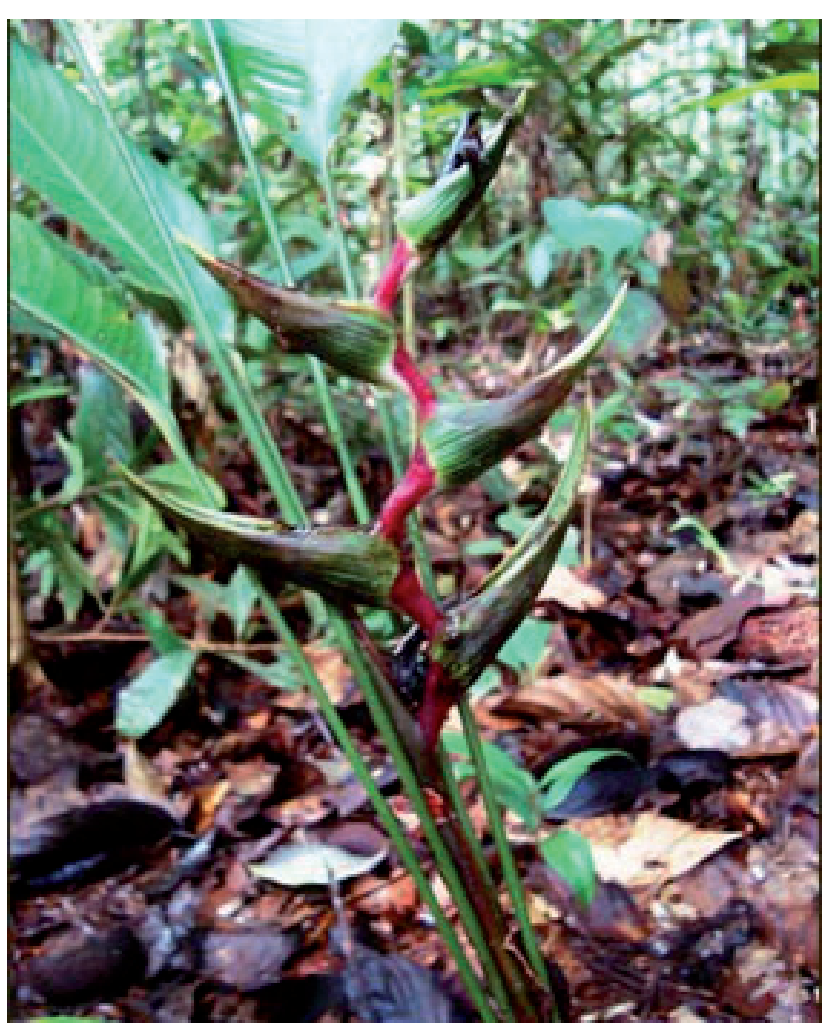

Figura 6. Heliconia tenebrosa.

Figure 6. Heliconia tenebrosa.

efarinosa) f. constricta Barreiros; (6) H. farinosa (var. efarinosa) f. magna Barreiros; (7) H. farinosa (var. efarinosa) f. angusta Barreiros; (8) H. farinosa (var. efarinosa) f. versatilis Barreiros (CASTRO et al. 2007).

Planta de hábito musoide, com 1,0 a 3,5 metros de altura. As folhas apresentam uma camada cerosa típica. A inflorescência é ereta, de 14,0 a 35,0 cm de comprimento, com raque reta, de coloração vermelha. As brácteas persistentes, em número de 5 a 11 por inflorescência, distribuem-se em um mesmo plano. Estão inseridas em um ângulo de 35 a 


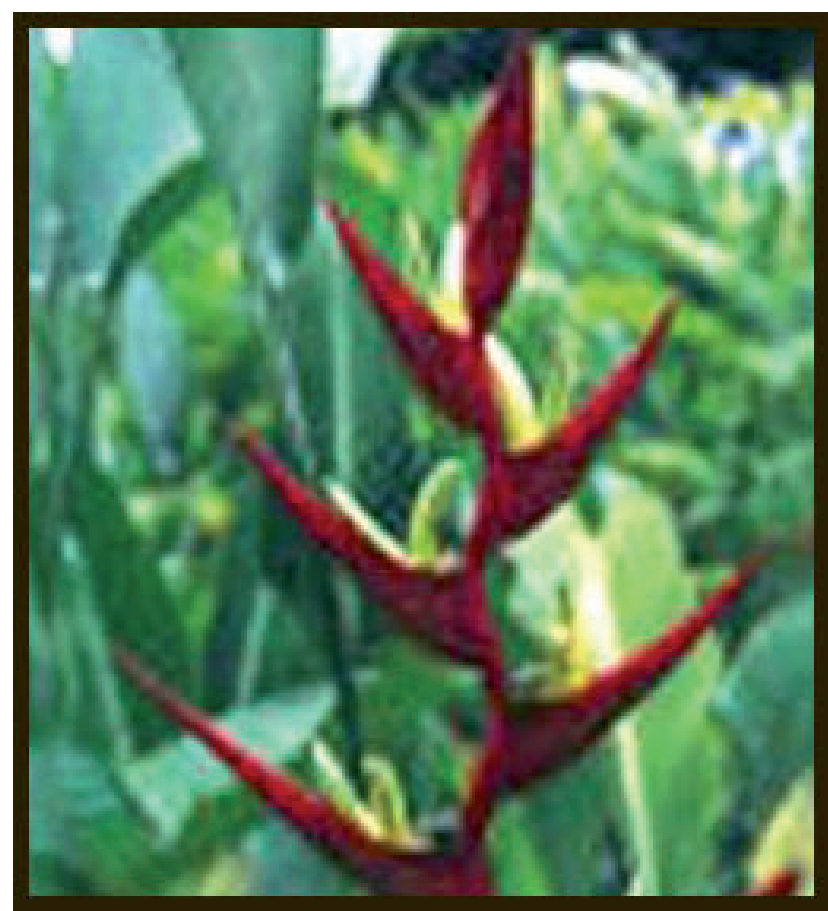

Figura 7. Heliconia farinosa.

Figure 7. Heliconia farinosa.

$90^{\circ}$ em relação ao eixo da inflorescência e têm coloração vermelha. As flores são parabólicas, de 3 a 5 por bráctea, torcidas e levemente esverdeadas (BARREIROS, 1974a).

Ocorre naturalmente em altitudes de 50 a 600 metros, nos Estados do Rio de Janeiro, São Paulo, Paraná, Santa Catarina e Rio Grande do Sul, em matas úmidas e sombreadas de regiões litorâneas. Nessas regiões, tem florescimento de julho a novembro (BARREIROS, 1974a).

Tem como característica as brácteas curvadas no ápice, flores parabólicas e torcidas na maturidade e semiexpostas na antese.

Difere da $H$. velloziana, espécie muito próxima, pelo menor tamanho da inflorescência, cerosidade das folhas e inflorescência glabra, e da $H$. sampaioana pela cerosidade das folhas e inflorescências sem pelos.

É uma planta de locais levemente sombreados, sendo utilizada como flor de corte.

A principal cultivar comercial é a Rio.

\subsubsection{H. kautzhiana Emygdio \& Santos}

Planta de hábito musoide, com 2,5 metros de altura. Apresenta inflorescência ereta, de 30,0 a 45,0 cm de comprimento, com raque sinuosa, de coloração vermelho-escarlate. As brácteas, em número de 7 a 15 por inflorescência, distribuem-se em planos diversos. Estão inseridas em um ângulo de 45 a $90^{\circ}$ em relação ao eixo da inflorescência e têm coloração vermelho-escarlate a vinho. As flores são quase retas, de amarelas a branco-esverdeadas em direção ao ápice (MELLO FILHO \& SANTOS, 1987a).

Ocorre naturalmente em altitudes de 700 a 800 metros, endêmica do Estado do Espírito Santo, em florestas úmidas e na vegetação secundária (MELLO FILHO \& SANTOS, 1987a).

Assemelha-se à $H$. velloziana, dela diferindo pelo indumento da inflorescência.
Espécie não cultivada e só conhecida em sua região de origem.

\subsubsection{H. rivularis Emygdio \& Santos (Figura 8).}

Planta de hábito musoide, com 2,0 a 3,0 metros de altura. Apresenta inflorescência ereta, de 30,0 a 41,0 cm de comprimento, com raque sinuosa, vermelha e levemente pubérula. As brácteas persistentes em número de 6 a 15 por inflorescência, distribuem-se em planos diversos. Estão inseridas em um ângulo de 25 a $70^{\circ}$ em relação ao eixo da inflorescência, têm coloração externa vermelha escura com ápice amarelo e internamente alaranjadas, sendo levemente pilosas. As flores são levemente curvadas, de 10 a 16 por bráctea e amarelas (MELLO FILHO \& SANTOS, 1977).

Ocorre naturalmente em altitudes do nível do mar a 300 metros nos Estados do Rio de Janeiro e São Paulo, em bordas de florestas úmidas e vegetação secundária (MELLO FILHO \& SANTOS, 1977).

Tem como característica brácteas largas, levemente pilosas, de coloração vermelha viva. As flores, em grande número por bráctea, são de coloração amarelo intenso.

Espécie que vegeta e floresce bem em locais de leve a moderada sombra, tem uso restrito em jardins.

\subsubsection{H. sampaioana Mello Filho (Figura 9)}

Planta de hábito musoide, com 1,5 a 2,0 metros de altura. Apresenta inflorescência ereta, de 15,0 a 40,0 cm de
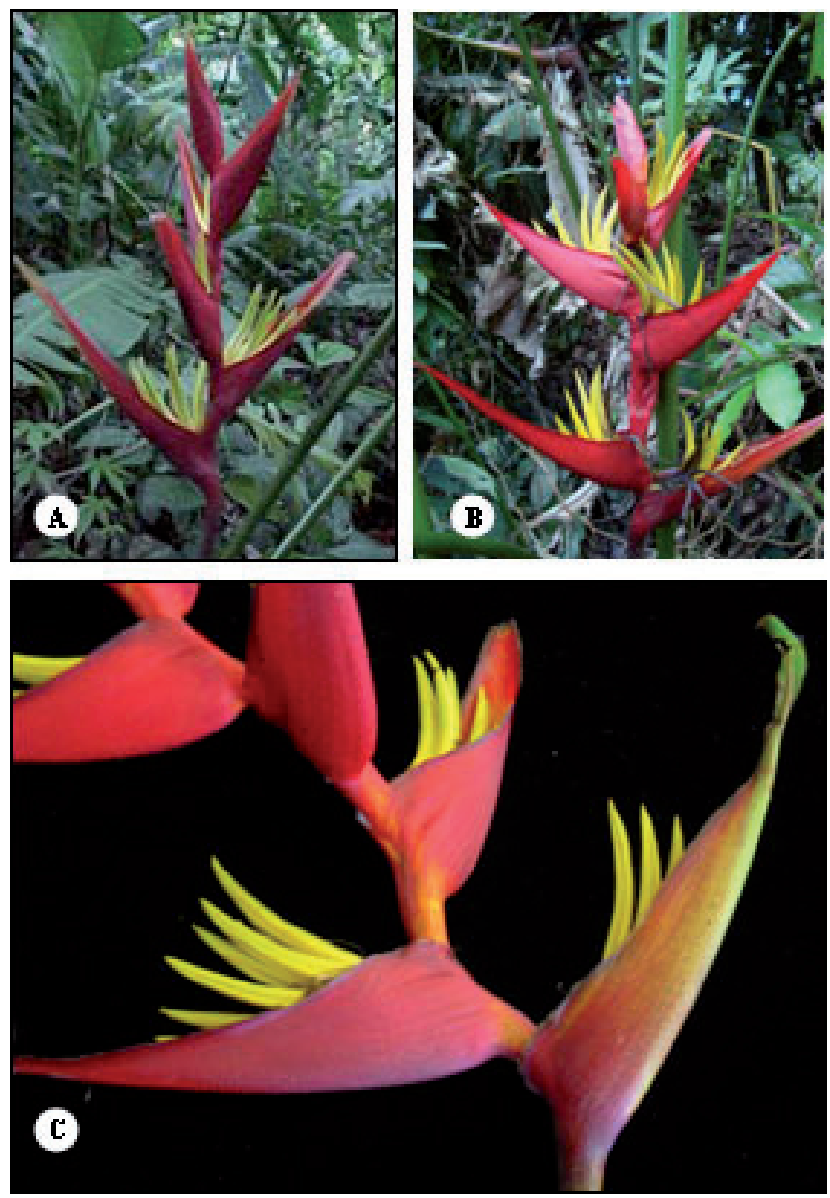

Figura 8. Heliconia rivularis: a e b) distribuição espiralada de brácteas; c) grande número de flores nas brácteas.

Figure 8. Heliconia rivularis: a and b) bracts spiral distribution; c) large number of flowers on the bracts. 
comprimento, com raque sinuosa, vermelho-vinosa e pubérula. As brácteas, em número de 5 a 10 por inflorescência, distribuem-se em um mesmo plano. Estão inseridas em um ângulo de 35 a $90^{\circ}$ em relação ao eixo da inflorescência e têm coloração externa vermelha e interna alaranjada. As flores são curvas, de 5 a 9 por bráctea e de coloração esverdeada (MELLO FILHO \& SANTOS, 1976).

Ocorre naturalmente em altitudes de 400 a 1.000 metros, nos Estados do Rio de Janeiro, Espírito Santo e São Paulo, em florestas úmidas (MELLO FILHO \& SANTOS, 1976).

Distingue-se da $H$. farinosa pela pilosidade da inflorescência, folhas não pruinosas e ovário colorido.

Espécie não cultivada, embora exista comércio de inflorescências por comunidades tradicionais no sudeste do país, para uso como flor de corte.

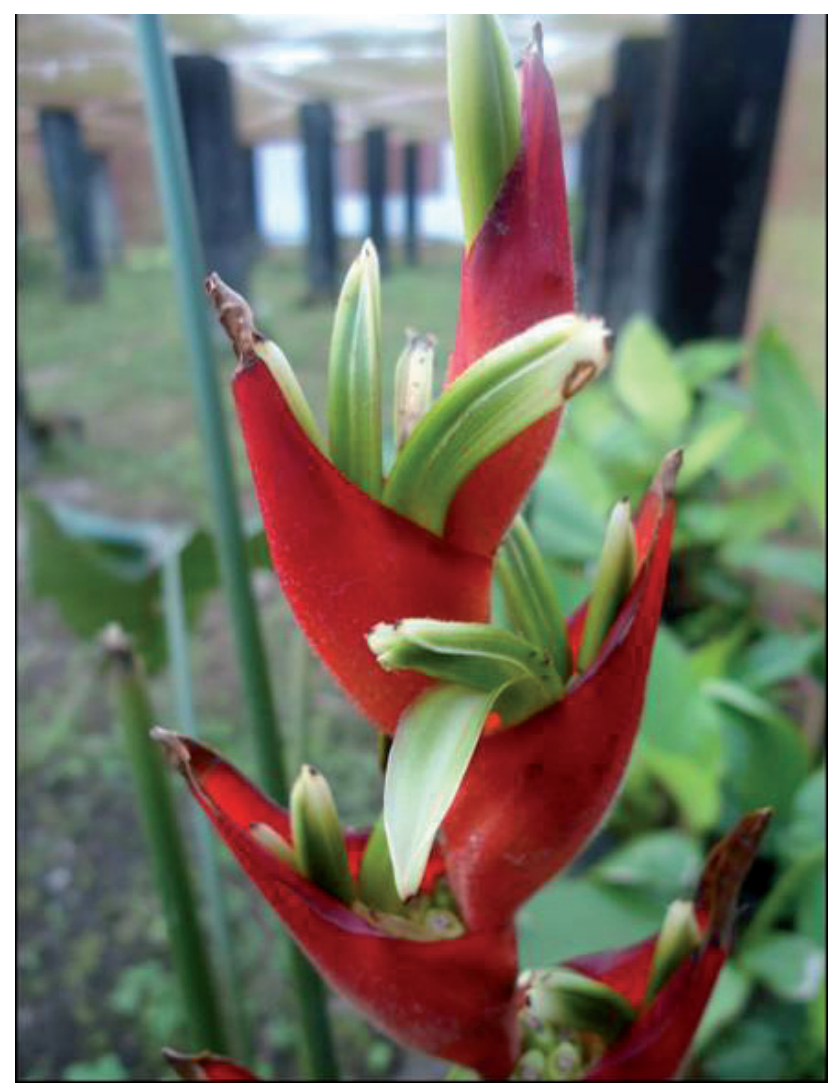

Figura 9. Heliconia sampaioana.

Figure 9. Heliconia sampaioana.

\subsubsection{H. velloziana Emygdio (Figura 10).}

Planta de hábito musoide, com até 5,0 metros de altura, algumas vezes com camada de cerosidade no verso das folhas. Apresenta inflorescência ereta, de 25,0 a 70,0 cm de comprimento, com raque reta, vermelho-alaranjada. As brácteas persistentes, em número de 7 a 14 por inflorescência, distribuem-se em um mesmo plano. Estão inseridas em um ângulo de 40 a $90^{\circ}$ em relação ao eixo da inflorescência e têm coloração vermelho-alaranjada externamente e amarelada internamente. A bráctea inferior se prolonga, algumas vezes, em um apêndice foliáceo. As flores são de 5 a 15 por bráctea e esverdeadas (MELLO FILHO, 1975).

Ocorre naturalmente em altitudes do nível do mar a 800 metros nos Estados do Rio de Janeiro, São Paulo, Paraná e Santa Catarina, na Mata Atlântica, em locais úmidos e sombreados. Na região de ocorrência natural, floresce de maio a outubro (MELLO FILHO, 1975).

Difere-se da $H$. farinosa pelo maior número de brácteas, maior número de flores e maior vigor.

Espécie cultivada em aldeias indígenas na região do litoral norte do Estado de São Paulo, para uso como flor de corte.
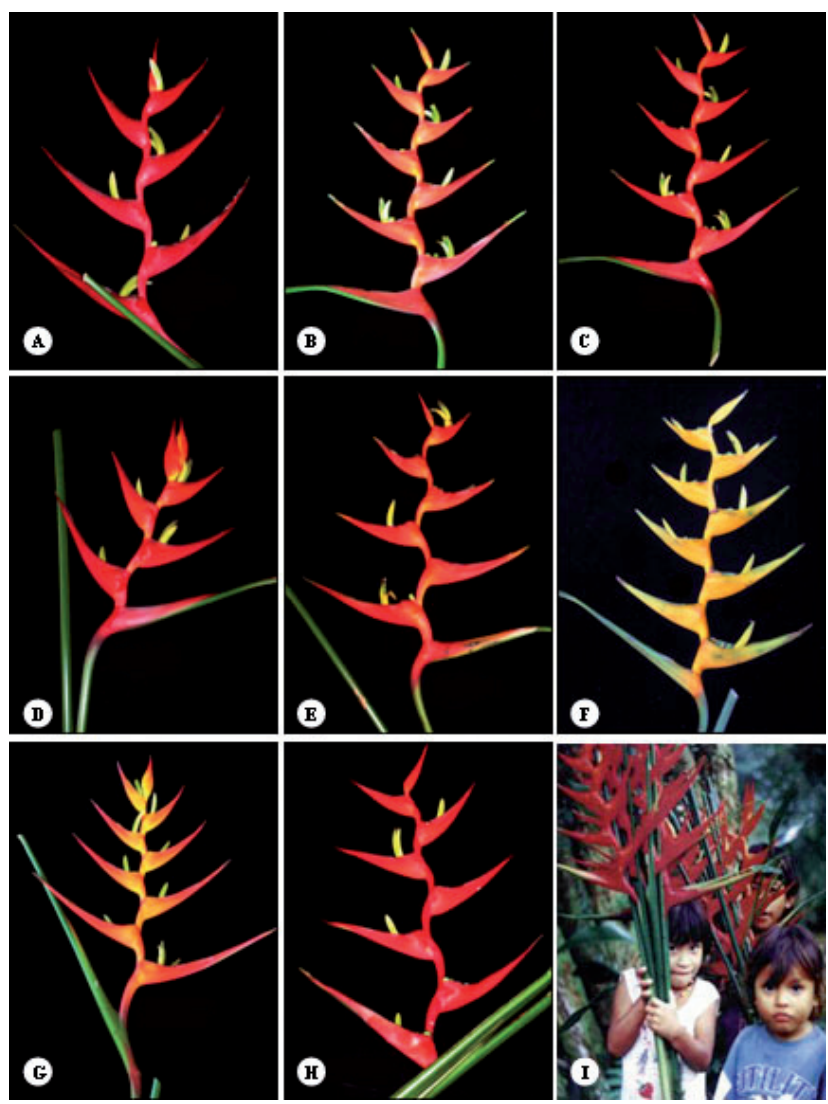

Figura 10. Heliconia velloziana: a-h) formas em cultivo na coleção de Zingiberales - IAC/APTA; i) ilustração de capa RBHO 3 (2), 1997, evidenciando resultado de projeto desenvolvido junto a aldeia Guarani, no município de Bertioga, SP.

Figure 10. Heliconia velloziana: a-h) cultivated genotypes in the collection of Zingiberales - IAC/APTA; i) cover art RBHO 3 (2), 1997, showing results of a project developed with the Guarani Village, in Bertioga, SP.

\section{Subgen. Stenochlamys}

\subsection{Sect. Lanea L. Anderss.}

\subsubsection{H. aemygdiana Burle-Marx ssp. Aemygdiana} (Figura 11).

Sinonímias: (1) H. dasyantha Kock \& Buché var. rosea Loes.; (2) H. zygolopha Lane ex Santos; (3) H. aemygdiana Burle Marx (CASTRO et al. 2007).

Planta de hábito musoide, com 1,0 a 4,0 metros de altura. Apresenta inflorescência ereta, de 25,0 a 55,0 cm de comprimento, com raque amarela ou amarelo-alaranjada densamente pilosa. As brácteas persistentes, em número de 5 a 15 por inflorescência, distribuem-se em planos diver- 
sos. Estão inseridas em um ângulo de 65 a $135^{\circ}$ em relação ao eixo da inflorescência, têm coloração vermelha, púrpura ou alaranjada, frequentemente amareladas na base quando a raque é amarela, com as inferiores mais ou menos esverdeadas na base. As flores são levemente parabólicas, densamente pilosas, de 6 a 9 por bráctea, e de coloração verde claro a amarelas (BURLE MARX, 1974).

Ocorre naturalmente em altitudes de 250 a 1.300 metros, no norte do Estado do Rio de Janeiro, no Espírito Santo e em Minas Gerais, em locais de sombra intensa nas mar- gens de rios, borda de matas e na vegetação secundária de florestas úmidas. Na região de ocorrência natural, floresce de agosto a março (BURLE MARX, 1974).

Nas aldeias indígenas dos Estados do Rio de Janeiro e Espírito Santo é conhecida como "pacouvavu".

É distinguida de outras espécies por suas flores grandes, hirsutas.

Espécie sem cultivo comercial identificado no Brasil, embora existam registros de duas cultivares comerciais: Enchanted Forest e Purple Peru.
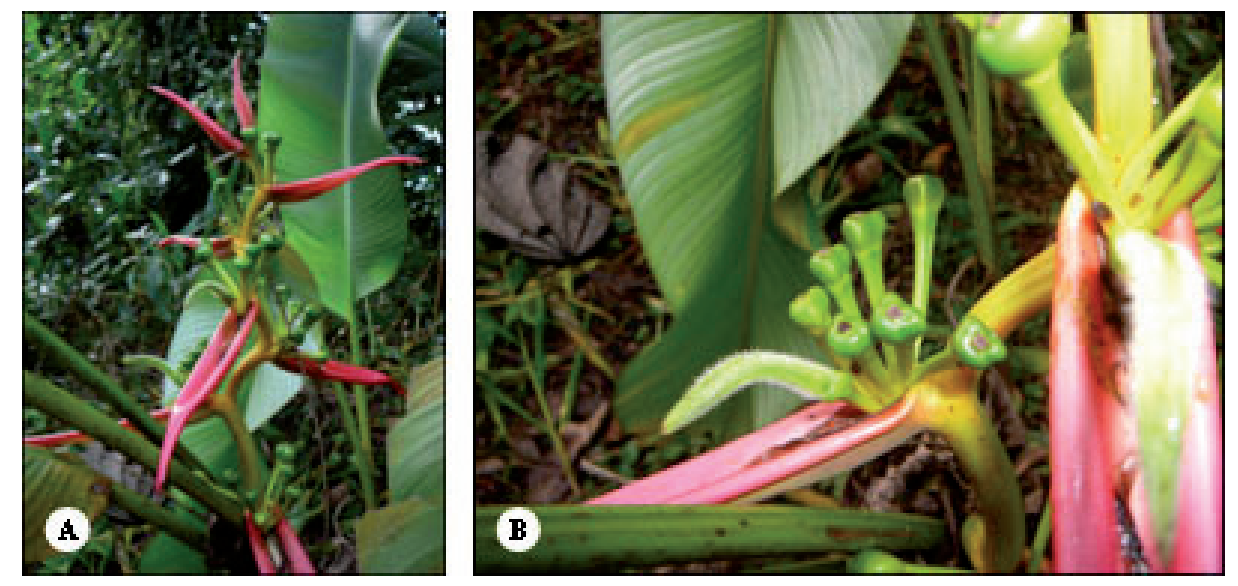

Figura 11. Heliconia aemygdiana: a) indivíduo em população natural; b) detalhe de flor e frutos em formação.

Figure 11. Heliconia aemygdiana: a) plant in natural population; b) flower and fruits formation detail.

\subsubsection{H. pseudoaemygdiana Emygdio \& Santos (Fi- gura 12)}

Planta de hábito musoide, de 1,0 a 2,0 metros de altura. Apresenta inflorescência ereta, de 38,0 a 52,0 cm de comprimento, com raque espiralada, amarela esverdeada na base e verde no ápice até amarelo-avermelhada na base e amarela no ápice e glabra. As brácteas, em número de 15 a 30 por inflorescência, distribuem-se em planos diversos. Estão inseridas em um ângulo de 40 a $110^{\circ}$ em relação ao eixo da inflorescência e têm coloração verde amarelada a completamente amarela externamente e vermelho-alaranjada a amarelo-alaranjada internamente. As flores são de 20 a 30 por bráctea com coloração amarelada ou amareloesverdeado (MELLO FILHO \& SANTOS, 1983).

Ocorre naturalmente em altitudes de 400 a 800 metros, nos Estados do Rio de Janeiro, Espírito Santo e na Bahia, em clareiras e na vegetação secundária de florestas úmidas (MELLO FILHO \& SANTOS, 1983).

É diferenciada da H. aemygdiana pelas flores glabras e forma do estaminódio. Também chamam atenção os seus ovários totalmente projetados para fora das brácteas.

Cultivada a pleno sol ou local levemente sombreado, tem emprego em jardins. Pode ser considerada espécie invasora devido à facilidade com que se propaga através de sementes dispersas por pássaros.

A principal cultivar comercial é a Birdiana.

\subsection{Sect. Stenochlamys (Baker) Schum.}

\subsubsection{H. acuminata L. C. Rich. (Figura 13).}

Sinonímias: (1) H. psittacorum L.f. var. flexuosa Peter-
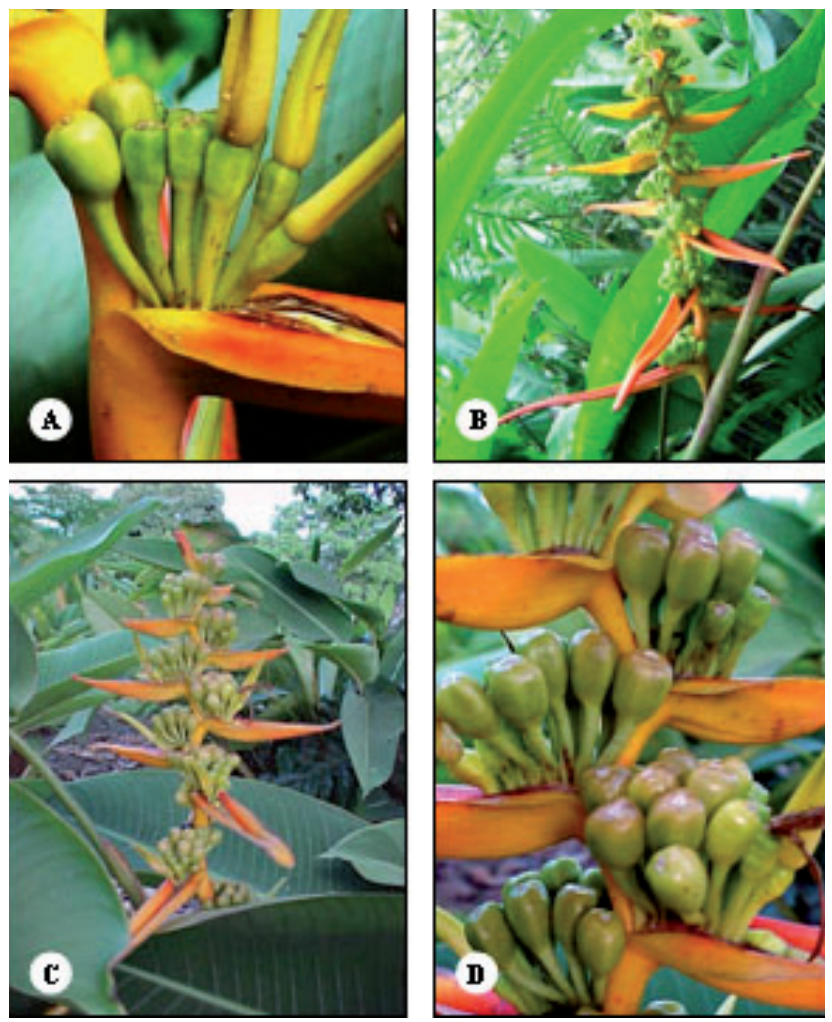

Figura 12. Heliconia pseudoaemygdiana: a) flor e frutos em formação; b) indivíduo em população natural; c) cultivar Birdiana; d) frutos em formação.

Figure 12. Heliconia pseudoaemygdiana: a) flower and fruits in formation; b) plant in natural population; c) cultivar Birdiana; d) fruits formation. 
sen; (2) H. roseoflava Loes.; (3) H. tarumaensis Barreiros (CASTRO et al. 2007).

Planta de hábito musoide, com 0,5 a 2,0 metros de altura. Apresenta inflorescência ereta, de 10,0 a $20,0 \mathrm{~cm}$ de comprimento, com raque sinuosa, da mesma cor da bráctea e glabra a densamente pubérula. As brácteas persistentes, retas ou uniformemente curvadas, em número de 2 a 10 por inflorescência, distribuem-se em um mesmo plano. Estão inseridas em um ângulo de 55 a $100^{\circ}$ em relação ao eixo da inflorescência, exceto a $H$. acuminata subsp. Psittacorastra, que tem ângulo de 10 a $40^{\circ}$. As brácteas são de coloração vermelha, alaranjada ou amarelas, mais brilhantes externamente que internamente, glabras a densamente pilosas. As flores retas ou uniformemente curvadas, 6 a 15 por bráctea, são verde oliva opaco com ápice esbranquiçado ou alaranjado claro para branco, alaranjadas ou amarelas com pintas subapicais em forma de olho verde ou enegrecidas (ANDERSSON, 1985).

No Brasil são três as subespécies de ocorrência natural. A $H$. acuminata subsp. psittacorastra tem folhas estreitas, inflorescências pequenas e ângulo menor que $45^{\circ}$, flores grandes com 43-56 mm, com manchas no ápice em forma de olho e ocorre no Estado do Amazonas. A H. acuminata subsp. acuminata tem flores pequenas com 27 a $45 \mathrm{~mm}$ e sem manchas. O ângulo de inserção das brácteas varia de 40 a $95^{\circ}$. Ocorre nos Estados do Amazonas e Amapá. A H. acuminata subsp. occidentalis tem flores grandes de 39 a $56 \mathrm{~mm}$, com manchas em forma de olho no ápice, pilosidade e espatas inseridas em ângulo de 55 a $100^{\circ}$, de coloração amarelo brilhante e folhas glaucas na face inferior.
Ocorre nos Estados do Pará, Amazonas, Rondônia e Acre (ANDERSSON, 1985).

As três subespécies ocorrem naturalmente em altitudes de 700 a 900 metros, em florestas fechadas, úmidas, embora também sejam encontradas floridas em clareiras e em crescimentos secundários (ANDERSSON, 1985).

São distinguidas pelo indumento na nervura central e inflorescência, brácteas e flores abertas. Floresce nas regiões de ocorrência natural de outubro a março.

A H. acuminata difere da H. psittacorum por ser mais robusta e da $H$. timothei pela coloração das brácteas, que, nesta espécie são esverdeadas externamente e púrpura internamente e por suas flores grandes e uniformemente coloridas.

Espécie pouco difundida da qual se encontram alguns cultivos na região norte do país, principalmente em Manaus/AM, onde tem uso em jardins.

As principais cultivares comerciais são: Cheri R., Ruby, Tarumã e Yellow Waltz.

\subsubsection{H. angusta Vell. (Figura 14).}

Sinonímias: (1) H. bicolor Bentham; (2) H. angustifolia Hooker; (3) H. bidendata Barreiros; (4) H. simulans Lane ex Barreiros; (5) H. laneana Barreiros; (6) H. laneana Barr. f. flava Barreiros $-H$. laneana Barr. var. flava (Barr.) Santos; (7) H. laneana Barr. f. elatior Barreiros; (8) H. aurorea Emygdio \& Santos; (9) H. citrina Emygdio \& Santos; (10) H. fluminensis Emygdio \& Santos; (11) H. lacletteana Emygdio \& Santos; (12) H. brasiliensis auct. non Hook (CASTRO et al. 2007).

Planta de hábito musoide, com 1,0 a 3,0 metros de al-
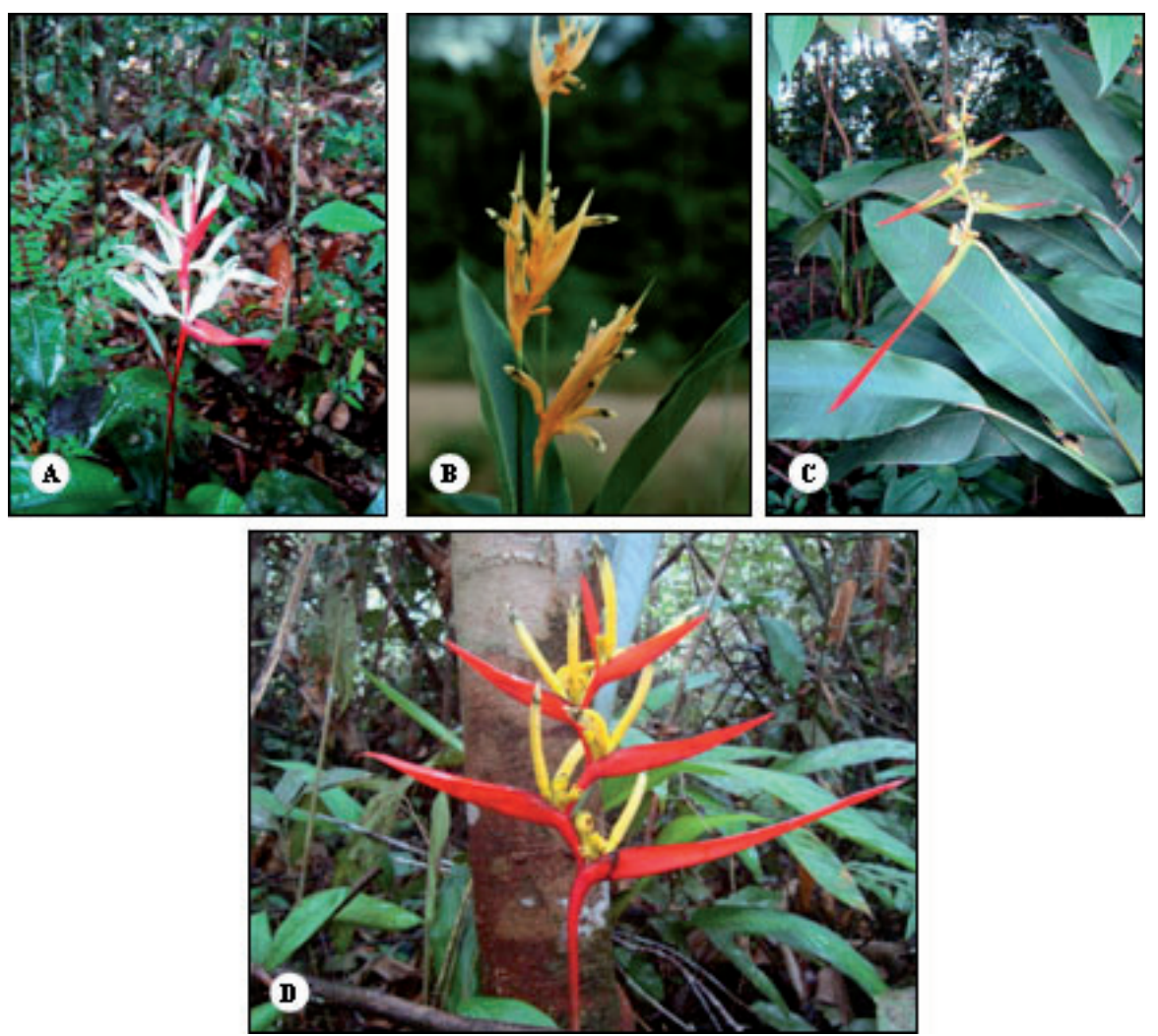

Figura 13. Heliconia acuminata - indivíduos em população natural: a) Heliconia acuminata ssp imaculata b) Heliconia acuminata ssp. psittacorastra; c) Heliconia acuminata ssp. acuminata d) Heliconia acuminada ssp. occidentalis.

Figure 13. Heliconia acuminata - plants in natural population: a) Heliconia acuminata ssp imaculata b) Heliconia acuminata ssp. psittacorastra; c) Heliconia acuminata ssp. acuminata d) Heliconia acuminada ssp. occidentalis. 
tura, que constitui um complexo polimórfico. Apresenta inflorescência ereta, de 7,0 a $35 \mathrm{~cm}$ de comprimento, com raque reta, de cor semelhante à cor das brácteas e glabra. As brácteas em número de 3 a 11 por inflorescência distribuem-se em um mesmo plano. Estão inseridas em um ângulo de 30 a $85^{\circ}$ em relação ao eixo da inflorescência, têm coloração amarela, ou laranja ou vermelha intensa a escarlate e/ou tons dessas cores. As flores são de 5 a 7 por bráctea e de coloração branca (ANDERSSON, 1985).

Ocorre naturalmente em altitudes de 600 a 800 metros, mas podem ser, algumas vezes, encontradas no nível do mar, nos Estados do Rio de Janeiro, Minas Gerais, Espírito
Santo e São Paulo, em sub-bosques da Mata Atlântica. Nas regiões de ocorrência natural, floresce de maio a setembro (ANDERSSON, 1985).

Tem o nome popular, na região de ocorrência natural, de bico de guará. Reconhecida pela forma triangular da inflorescência e coloração intensa das brácteas. Espécie de locais levemente sombreados e com temperaturas mais amenas, sendo, sobretudo, cultivada no Sudeste do país e tem uso como flor de corte.

As principais cultivares comerciais são: Flava, Holiday, Large Christmans, March Christmans, Orange Christmans e Yellow Christmans.
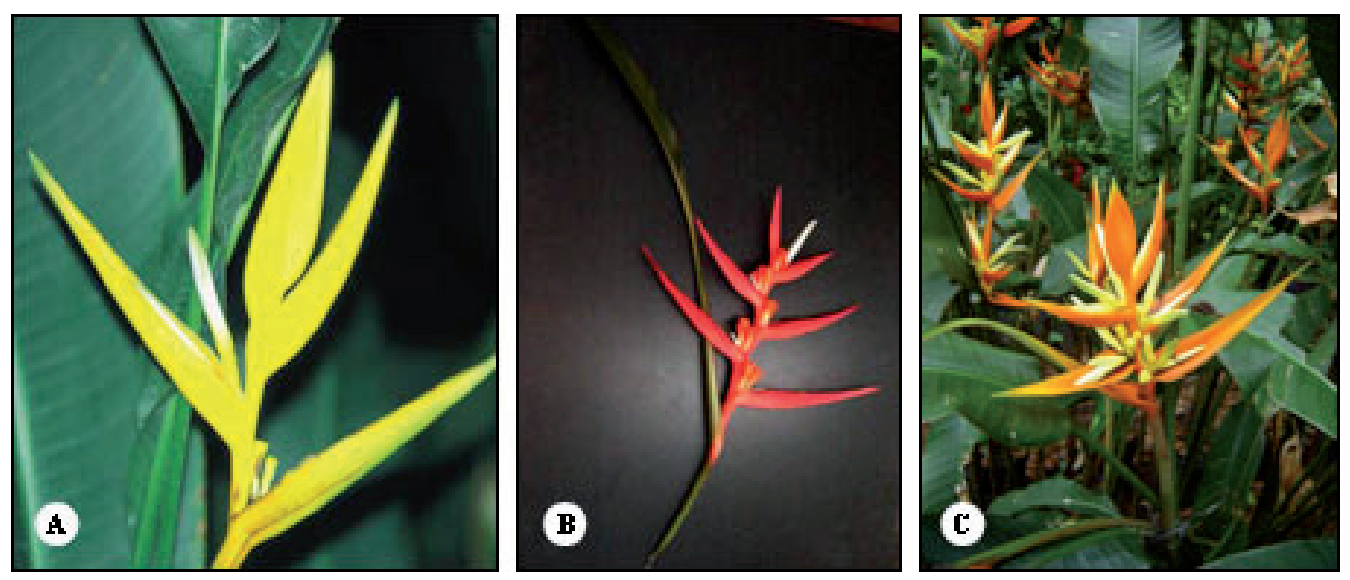

Figura 14. Heliconia angusta: a) cultivar Flava; b) inflorescência de indivíduo de população natural; c) cultivar Orange Christmans.

Figure 14. Heliconia angusta: a) cultivar Flava; b) inflorescence of plant in natural population; c) cultivar Orange Christmans.

\subsubsection{H. psittacorum L.f. (Figura 15).}

Sinonímias: (1) H. ballia L. C. Richard.; (2) H. marantifolia Shaw; (3) H. swartziana Roemer \& Schultes; (4) H. cannoidea L.C. Rich - H. hirsuta L. f. var. cannoidea (L.C.Rich.) Baker; (5) H. schomburgkiana Kl. - H. psittacorum L. f. var. schomburgkiana (K1.) Baker; H. andrewsii K1.; (6) H. psittacorum L. f. var. B spathacea Eichler ex Petersen; (7) H. psittacorum L. f. var. y robusta Eichler ex Petersen; (8) H. refracta Martens ex Baker; (9) H. silvestris (Gleason) L. B. Smith; (10) H. psittacorum L. f. rhizomatosa Aristeguieta; (11) H. goiasensis Barreiros; (12) H. bahiensis Barreiros (CASTRO et al. 2007).

Planta de hábito musoide, delgada com 0,5 a 2,0 metros de altura. Apresenta inflorescência ereta, de 7,0 a 18,0 cm de comprimento, com raque reta e glabra. As brácteas, em número de 2 a 7 por inflorescência, uniformemente curvadas e com leve camada de cerosidade, distribuem-se em um mesmo plano. Estão inseridas em um ângulo de 10 a $65^{\circ}$ em relação ao eixo da inflorescência, têm coloração rósea ou alaranjada e avermelhada na face externa, às vezes esverdeadas e avermelhadas ou púrpura na face interna em direção ao ápice. As flores são retas ou levemente curvadas, de 5 a 8 por bráctea, de coloração amarelada, alaranjada ou avermelhada, excepcionalmente branca, com manchas verde escura em forma de olho no ápice (ANDERSSON, 1985).

Ocorre naturalmente em altitudes do nível do mar a 800 metros, nos Estados do Amazonas, Rondônia, Amapá, Ro- raima, Pará, Maranhão, Ceará, Rio Grande do Norte, Paraíba, Pernambuco, Alagoas, Sergipe, Bahia Espírito Santo, Rio de Janeiro, Goiás, Mato Grosso do Sul e Mato Grosso, em locais úmidos e secos, em florestas e bordas de mata, mas também em restingas e a pleno sol, neste caso, com folhas mais estreitadas. Floresce o ano todo com pico entre setembro e janeiro (ANDERSSON, 1985).

É diferenciada de outras espécies por serem plantas baixas, delgadas com inflorescências com poucas e curtas brácteas.

Espécie com um grande número de variedades, a maioria cultivada a pleno sol e com uso tanto como flor de corte, como em jardins formando bordaduras, cercas vivas e maciços florais.

As principais cultivares comerciais são: Andrômeda, Black Cherry, Borinquen Midnight, Choconiana, Flamingo, Fuchsia, Kathy, Lady Di, Lena, Lílian, Lizette, Parakeet, Peter Bacon, Petra, Pink, Ruby, St. Vincent Red, Sassy, Shamrock, Strawberries and Cream, Suriname Sassy, Kaliedoscope, Adrian's Red, Dwarf Pink, Rubra, Silvestris, Coverdia Red, Doublé B Gold, Kanasayana, Karen, Marion, Sybel e Tay.

\subsubsection{H. richardiana Miq. (Figura 16).}

Sinonímia: H. glauca Poiteau ex Verlot (CASTRO et al. 2007).

Planta de hábito musoide, com 1,0 a 2,0 metros de altura, com leve camada de cerosidade no verso das folhas. 

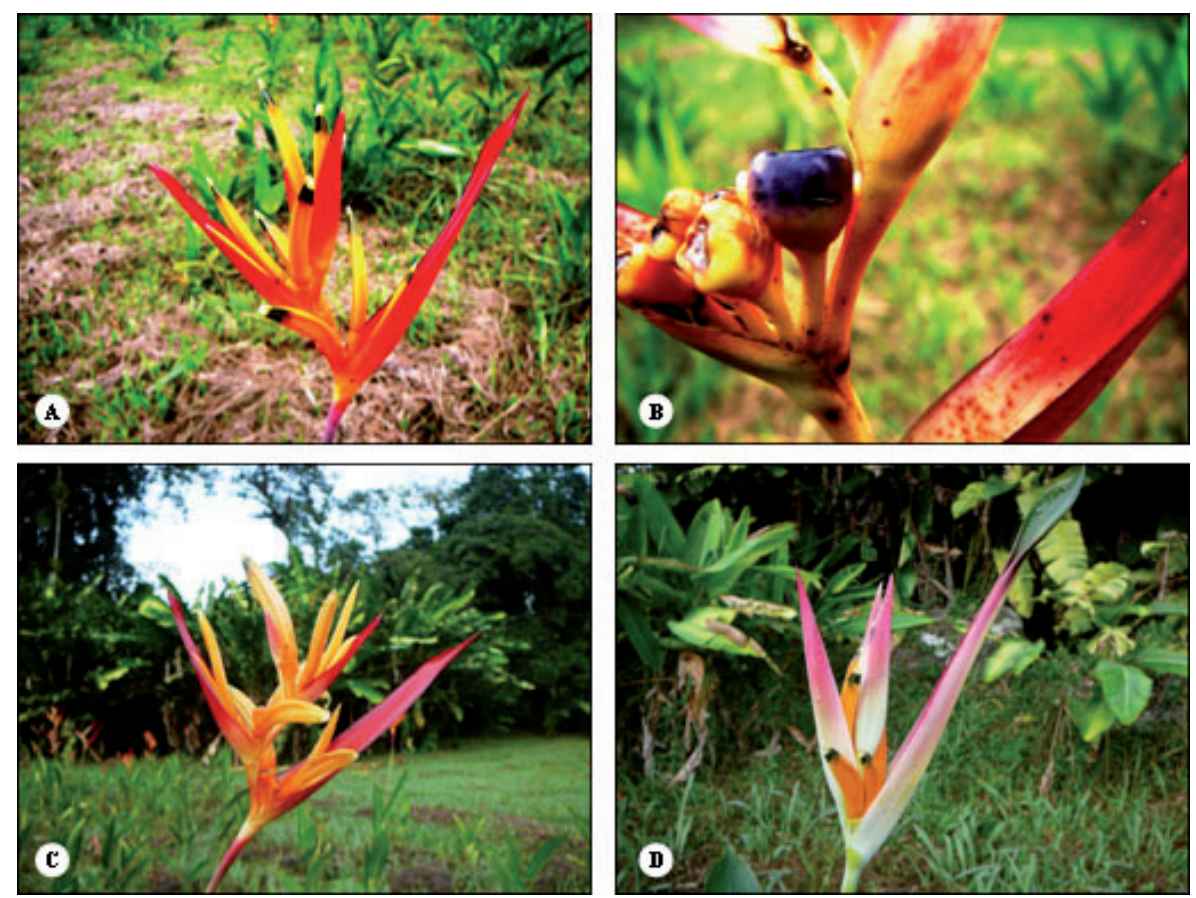

Figura 15. Heliconia psittacorum: a) cultivar Andromeda; b) detalhe de fruto maduro; c) cultivar Andromeda; d) cultivar Sassy.

Figure 15. Heliconia psittacorum: a) cultivar Andromeda; b) detail of mature fruit; c) cultivar Andromeda; d) cultivar Sassy.

Apresenta inflorescência ereta, de 14,0 a $25,0 \mathrm{~cm}$ de comprimento, com raque reta, alaranjada ou vermelho brilhante e levemente pubérula. As brácteas retas, em número de 4 a 7 por inflorescência, distribuem-se em um mesmo plano. Estão inseridas em um ângulo de 60 a $95^{\circ}$ em relação ao eixo da inflorescência e têm coloração avermelhada na base, a parte mais larga amarela ou amarelo-esverdeada, glabra ou com indumento. As flores são recurvadas, de 8 a 10 por bráctea, com coloração amarelo-esverdeada brilhante com pilosidade (ANDERSSON, 1985).

Ocorre naturalmente em altitudes de 300 a 800 metros, nos Estados do Pará, Maranhão, Bahia e Espírito Santo, em florestas úmidas fechadas e pequenas clareiras. Nessas regiões, floresce de setembro a janeiro (ANDERSSON, 1985).

É distinguida pela cor da inflorescência e formato recurvado do perianto.

Espécie sem cultivo comercial identificado.

\subsubsection{H. timothei L. Anderss.}

Planta de hábito musoide, com 0,8 a 1,5 metros de altura. Apresenta inflorescência ereta, de 10,0 a $20,0 \mathrm{~cm}$ de comprimento, com raque reta, amarelada. As brácteas, em número de 3 a 6 por inflorescência, distribuem-se em um mesmo plano. Estão inseridas em um ângulo de 40 a $75^{\circ}$ em relação ao eixo da inflorescência e têm coloração externa amarela com ápices avermelhados. As flores são retas com ápice saliente e indumento efêmero, de coloração verde pálido na base, verde mais escuro distalmente e brancas no ápice. Os frutos são azuis na maturidade e negros quando secos (ANDERSSON, 1985).

Ocorre naturalmente em altitudes de 400 a 800 metros, no Estado do Amazonas, em locais úmidos de florestas primárias ou secundárias ou em pequenas clareiras (AN-

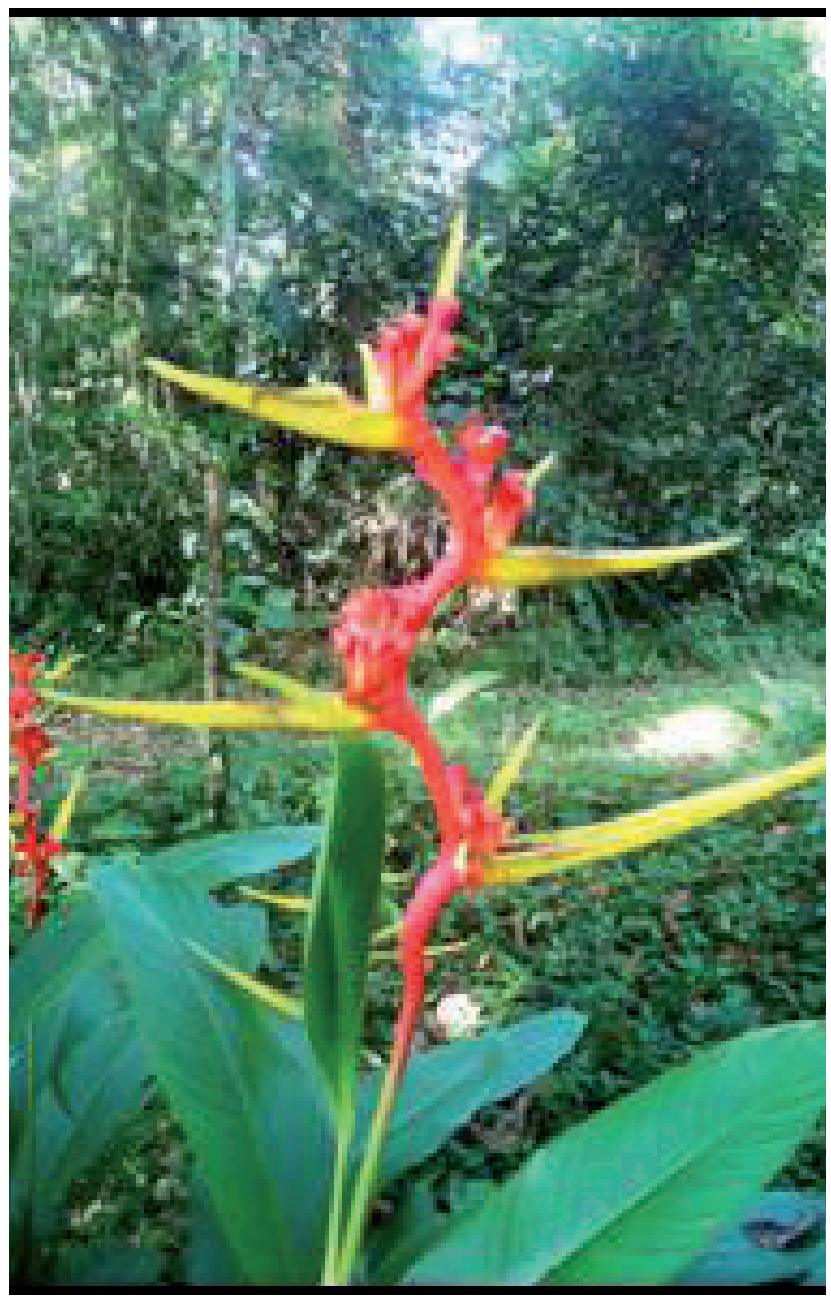

Figura 16. Heliconia richardiana.

Figure 16. Heliconia richardiana. 


\section{DERSSON, 1985).}

É distinguida pela forma da lâmina das folhas e espata aberta de coloração externa amarela e vermelha internamente e pelas flores verdes com ápice branco.

Espécie só conhecida em sua região de ocorrência natural.

\subsection{Sect. Proximochlamys Anderss.}

\subsubsection{H. densiflora Verlot (Figura 17).}

Planta de hábito musoide, com 1,0 a 3,0 metros de altura. Apresenta inflorescência ereta, de 13,0 a 25,0 cm de comprimento, com raque reta, glabra de coloração vermelha a alaranjada. As brácteas, em número de 5 a 9 por inflorescência, são levemente sobrepostas e distribuem-se em um mesmo plano. Estão inseridas em um ângulo de 5 a $25^{\circ}$ em relação ao eixo da inflorescência e têm coloração alaranjada para vermelha ou raramente amarelada cerosa. As flores são de 5 a 10 por bráctea, de coloração amarelada para alaranjada com manchas escuras em formato de olho em direção ao ápice, este esbranquiçado (ANDERSSON, 1985).

Ocorre naturalmente em altitudes de 200 a 800 metros, no sudeste da Amazônia nos Estados do Amazonas, Acre, Rondônia e Mato Grosso, em florestas fechadas e pequenas clareiras. Nessas regiões, floresce o ano todo, mas principalmente nos meses de setembro a março (ANDERSSON, 1985).

É diferenciada por ser uma planta vigorosa, com brácteas profundas e flores com manchas em forma de olho.

A H. densiflora subsp. angustifolia L. Andersson difere por ter brácteas menos sobrepostas e flores mais estreitas e mais curtas. Ocorre nos Estados do Amazonas, Amapá e Acre.

A H. densiflora subsp. densiflora de ocorrência no Estado do Amazonas compreende formas com folhas mais largas com longos pecíolos e inflorescências mais compactas.

Espécie sem cultivo comercial identificado no Brasil, adaptando-se bem para o uso em jardins, formando macios florais.

Existem registros em catálogos de produtores da América Central e Estados Unidos da cultivar comercial denominada Fire Flash.

\subsection{Sect. Lasia L. Anderss.}

\subsubsection{H. julianni Barreiros.}

Planta de hábito musoide, com 1,0 a 3,0 metros de altura e camada de cerosidade nas folhas. Apresenta inflorescência ereta, de 6,0 a $27,0 \mathrm{~cm}$ de comprimento, com raque reta a levemente sinuosa, amarela esverdeada e pubérula. As brácteas, em número de 3 a 8 por inflorescência, distribuem-se em um mesmo plano. Estão inseridas em um ângulo de 60 a $100^{\circ}$ em relação ao eixo da inflorescência e têm coloração carmim com base da mesma cor da raque e é glabra ou densamente pilosa. As flores são uniformemente curvadas, de 7 a 10 por bráctea, de coloração branca esverdeada para verde pálido com manchas em forma de olho no ápice (BARREIROS, 1976).

Ocorre naturalmente em altitudes de até 350 metros, nos Estados do Amazonas, Rondônia, Mato Grosso e Acre,

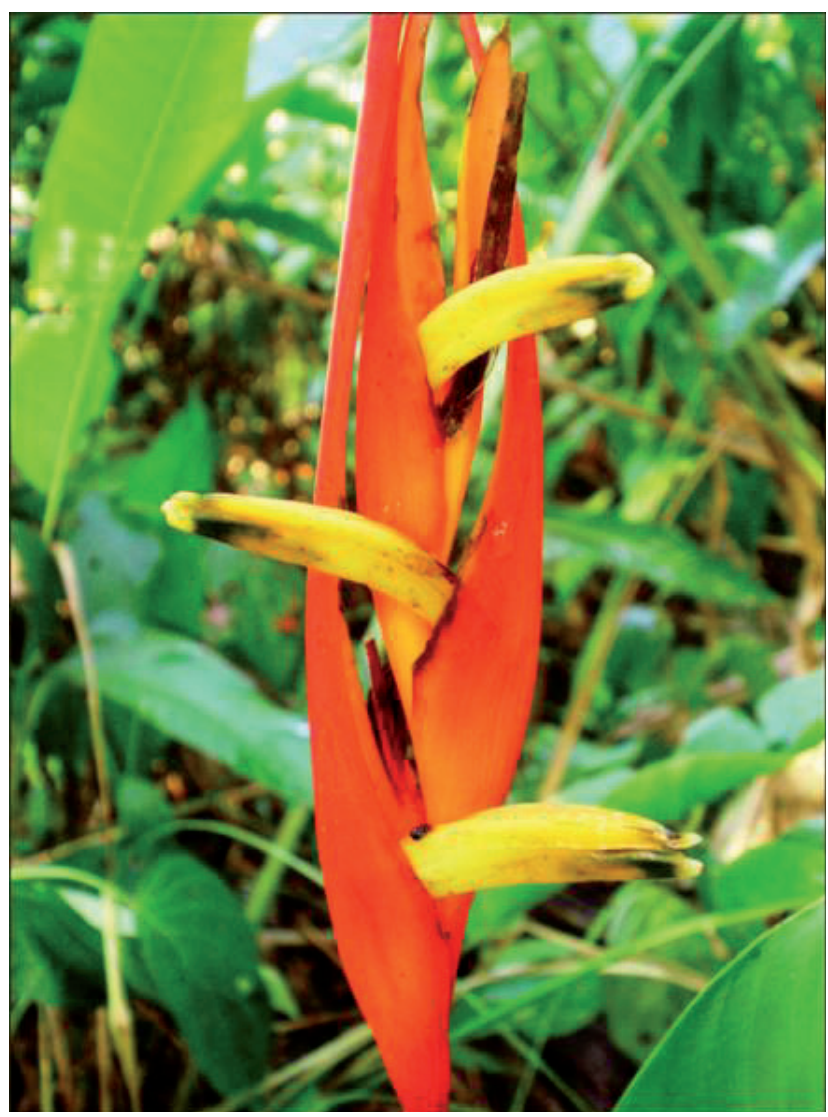

Figura 17. Heliconia densiflora var. angustifolia.

Figure 17. Heliconia densiflora var. angustifolia.

florestas úmidas na vegetação primária ou secundária. $\mathrm{Na}$ região de ocorrência natural, floresce de março a julho (BARREIROS, 1976).

Difere de outras espécies da Secção pelo pecíolo curto e pequenas folhas. Difere da H. lasiorachis pelo perianto nitidamente curvado, inflorescência e flores com mais indumento.

Espécie só conhecida na região de ocorrência natural.

\subsubsection{H. lasiorachis L. Anderss.}

Planta de hábito musoide, com 1,0 a 3,0 metros de altura, com camada cerosa na face inferior. Apresenta inflorescência ereta, de 10,0 a 21,0 cm de comprimento, com raque verde para amarelo-esverdeada, densamente hirsuta, com pelos grossos. As brácteas, em número de 5 a 13 por inflorescência, distribuem-se em um mesmo plano. Estão inseridas em um ângulo de 25 a $115^{\circ}$ em relação ao eixo da inflorescência e têm coloração escarlate com base da mesma cor da raque e são hirsutas. As flores são levemente curvadas, de coloração branco-esverdeada na base, gradualmente com tons de verde mais intenso em direção ao ápice, sendo este esbranquiçado (ANDERSSON, 1985).

Ocorre naturalmente em altitudes de 300 a 800 metros, nos Estados do Amazonas e Acre, em vegetação secundária ou primária de florestas degradadas (ANDERSSON, 1985).

É diferenciada por seu longo pecíolo e lâmina foliar, cerosidade das folhas, e flores pequenas uniformemente coloridas em vários tons de verde, mas não claramente manchadas. Difere da $H$. juliani no comprimento do pecíolo e tamanho da lâmina e, da $H$. velutina, pela cerosidade das 
folhas e de ambas, pelo comprimento do perianto.

Espécie só conhecida na região de ocorrência natural.

\subsubsection{H. velutina L. Anderss.}

Sinonímia: H. brasiliensis auct. non Hook (CASTRO et al. 2007).

Planta de hábito musoide, com 0,5 a 3,0 metros de altura. Apresenta inflorescência ereta, de 10,0 a $25,0 \mathrm{~cm}$ de comprimento, com raque amarela a verde e densamente pubérula. As brácteas, em número de 3 a 10 por inflorescência, distribuem-se em um mesmo plano. Estão inseridas em um ângulo de 25 a $115^{\circ}$ em relação ao eixo da inflorescência e têm coloração escarlate com base de mesma cor que a raque hirsuta. As flores são eretas ou uniformemente curvadas de coloração verde-clara. Os frutos são azuis na maturidade e negros quando secos (ANDERSSON, 1985).

Ocorre naturalmente em altitudes de até 750 metros, no Estado do Amazonas, em clareiras de florestas úmidas (ANDERSSON, 1985).

É distinguida por seu longo pecíolo e grande lâmina foliar sem cerosidade, flores retas, grandes e coloridas.

Espécie só conhecida na região de ocorrência natural.

\subsection{Sect. Cannastrum L. Anderss.}

\subsubsection{H. metallica Pl. \& Linden (Figura 18).}

Sinonímias: (1) H. vinosa Bull. Ex Ender; (2) H. nitens Hort.; (3) H. nana Rodríguez; (4) H. osaensis Cuf. var. rubescens Stiles (CASTRO et al. 2007).

Planta de hábito canoide, com 0,5 a 3,0 metros de altura e com a face inferior da folha com nuances de púrpura. Apresenta inflorescência ereta, de 7,0 a 25,0 cm de comprimento, com raque sinuosa, esverdeada para avermelhada. As brácteas, em número de 3 a 8 por inflorescência, distribuem-se em um mesmo plano. Estão inseridas em um ângulo de 25 a $90^{\circ}$ em relação ao eixo da inflorescência e têm coloração verde para vermelho e bráctea inferior frequentemente com apêndice. As flores são retas ou uniformente curvadas, de 5 a 10 por bráctea, róseas para púrpura e esbranquiçadas no ápice e mais claras em direção à base. Os frutos são azuis na maturidade e negros quando secos (ANDERSSON, 1985).

Ocorre naturalmente em altitudes do nível do mar a 1.000 metros, nos Estados do Amazonas e Acre, em margens de rios, em clareiras de florestas úmidas, ao longo de trilhas e estradas. Na região de ocorrência natural floresce de agosto a janeiro (ANDERSSON, 1985).

É diferenciada pelo perianto avermelhado, coloração do verso da folha e indumento das bainhas foliares.

Espécie sem cultivo comercial identificado.

\subsubsection{H. subulata R. \& P. (Figura 19).}

Sinonímias: (1) H. pearcei Rusby; (2) H. affinis Loes.; (3) H. burchelli Baker (CASTRO et al. 2007).

Planta de hábito canoide, com 1,0 a 3,0 metros de altura. Apresenta inflorescência ereta, de 6,0 a $20,0 \mathrm{~cm}$ de comprimento, com raque glabra. As brácteas, em número de 4 a 10 por inflorescência, distribuem-se em planos diversos. Estão inseridas em um ângulo de 35 a $100^{\circ}$ em relação ao eixo da inflorescência e têm coloração vermelha, raramente esverdeada. As flores são curvadas de coloração amarela

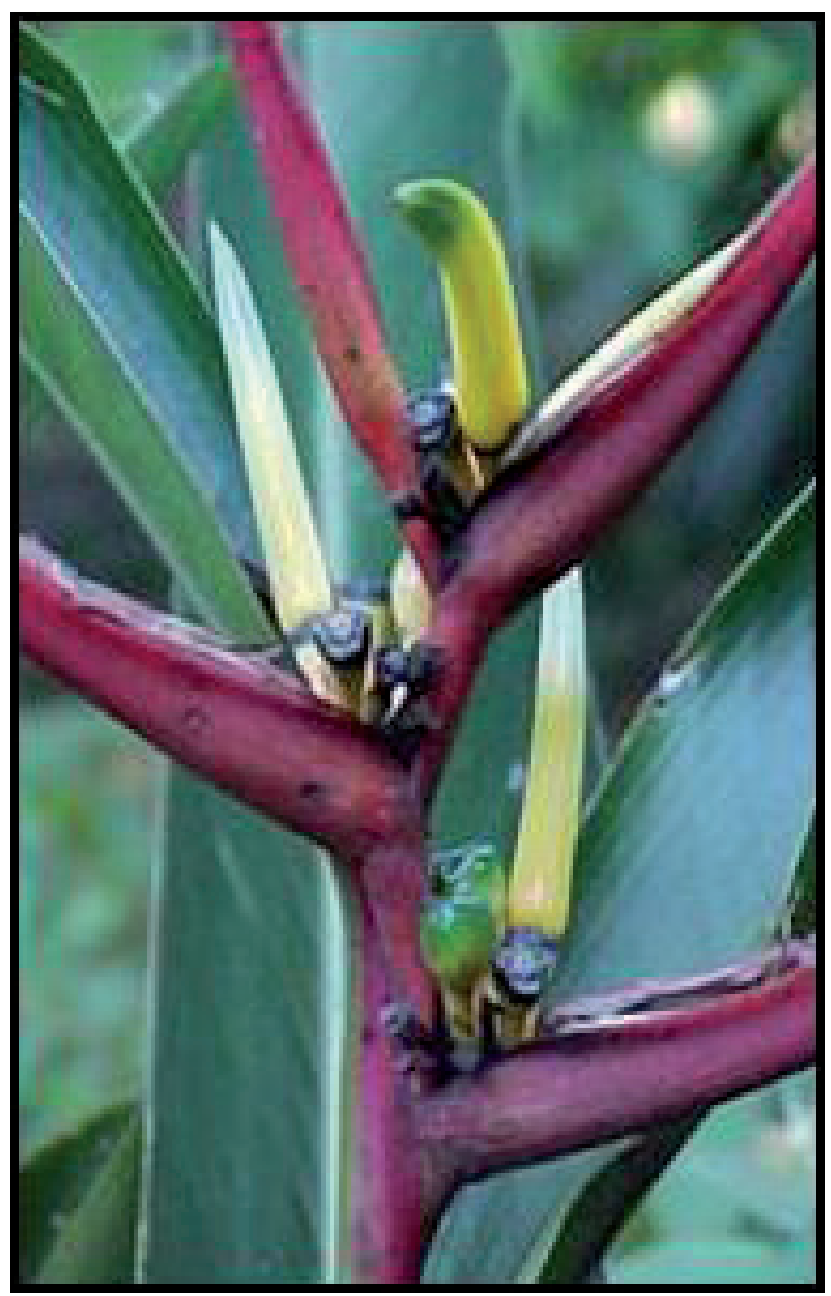

Figura 18. Heliconia metallica.

Figure 18. Heliconia metallica.

com nuances de verde distalmente, às vezes totalmente esverdeadas (ANDERSSON, 1985).

Ocorre naturalmente em altitudes de 700 a 1.400 metros, nos Estados de Minas Gerais, Goiás, Mato Grosso, Mato Grosso do Sul, São Paulo, Paraná e Rondônia, em margens de riachos e em clareiras de florestas úmidas. Floresce de setembro a dezembro.

Distinguida pelo curto pecíolo, limbo foliar oblongo com os lados paralelos e flores curvadas, amareladas a esverdeadas (ANDERSSON, 1985).

Espécie sem cultivo comercial identificado, mas que pode ser usada tanto como flor de corte como planta de jardim, formando maciços florais em locais de sombra moderada.

\subsection{Sect. Zingiberastrum L. Anderss.}

\subsubsection{H. apparicioi Barreiros.}

Planta de hábito zingiberoide, com 0,5 a 1,5 metros de altura. As folhas tem uma camada de cerosidade na face inferior. Apresenta inflorescência ereta, de 12,0 a 23,0 cm de comprimento, com raque sinuosa e glabra. As brácteas, em número de 4 a 8 por inflorescência, distribuem-se em planos diversos. Estão inseridas em um ângulo de 60 a $80^{\circ}$ em relação ao eixo da inflorescência, têm coloração verde ou amarelada para verde esbranquiçado na base, e róseo 

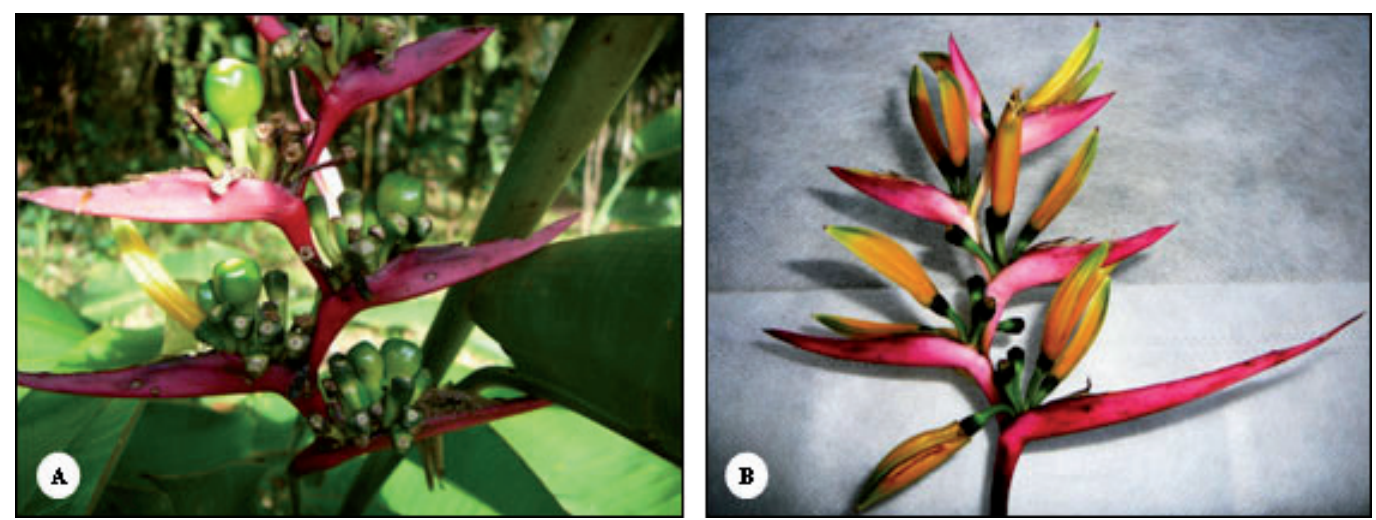

Figura 19. Heliconia subulata: a) inflorescência com frutos imaturos; b) inflorescência.

Figure 19. Heliconia subulata: a) inflorescence with immature fruits; b) inflorescence.

a róseo escura no ápice. As flores são retas ou levemente curvadas de coloração verde amarelada para verde na base, creme ou branco no ápice e rosa escuro na porção média (BARREIROS, 1976).

Ocorre naturalmente em altitudes de 200 a 800 metros, nos Estados do Acre e Amazonas, em áreas de florestas. Na região de origem, tem florescimento nos meses de agosto e setembro (BARREIROS, 1976).

Difere da $H$. schumanniana pela cerosidade nas lâminas foliares e cor do perianto.

Espécie só conhecida na região de ocorrência natural.

\subsubsection{H. hirsuta L. f. (Figura 20).}

Sinonímias: (1) H. bicolor Klotzsch non Bentham; (2) H. cannoidea L.C.Rich. var. villosa Petersen; (3) H. straminea (Griggs) Standley; (4) H. hirsuta L. f. var. villosula Loesener; (5) H. harrisiana (Griggs) L. B. Smith; (6) H. cardenasii L. B. Smith; (7) H. burle-marxii Emygdio; (8) $H$. costanensis Aristeguieta; (9) H. hirsuta L.f. var. rubiflora R.R.Smith; (10) H. cararensis Abalo \& Morales; (11) H. psittacorum auct. non L.f. (CASTRO et al. 2007).

Planta de hábito zingiberoide com 0,5 a 3,0 metros de altura e cerosidade mais ou menos distinta na face inferior. Apresenta inflorescência ereta, de 5,0 a 20,0 cm de comprimento, com raque reta, verde a amarelada ou alaranjada e glabra a levemente pubérula. As brácteas, em número de 3 a 10 por inflorescência, distribuem-se em mesmo plano. Estão inseridas em um ângulo de 10 a $100^{\circ}$ em relação ao eixo da inflorescência e tem coloração amarelo-esverdeada ou amarelo para alaranjado ou vermelha, às vezes com nuances de verde. As flores ocorrem de 10 a 12 por bráctea, são amarelas para alaranjadas ou vermelhas, com manchas verde escuras em forma de olho perto do ápice (ANDERSSON, 1985).

Ocorre naturalmente em altitudes do nível do mar a 1.250 metros, nos Estados Amazonas, Acre, Rondônia, Roraima, Pará, Mato Grosso, Mato Grosso do Sul, São Paulo, Goiás, Minas Gerais e Paraná, em florestas semidecíduas a pluviais, em pequenas clareiras e matas de galeria. Floresce o ano todo (ANDERSSON, 1985).

É distinguida pelo hábito zingiberoide, por possuír inflorescência distalmente pedunculada e perianto fortemente achatado com distintas manchas supapicais em formato de olho.

Espécie cultivada tanto a pleno sol como em locais le- vemente sombreados, com uso em jardins, principalmente em locais próximos a riachos e espelhos de água.

As principais cultivares comerciais são: Alicia, Chamaniana, Costa Flores, Darrell, Halloween, Pancoastal, Peru, Roberto Burle Marx, Trinidad Red, Twiggy, Yellow Panamá e, Jamaica Spikey.

\subsubsection{H. schumanniana Loes (Figura 21).}

Sinonímias: (1) H. aureorosea Loes.; (2) H. uleana Loes (CASTRO et al. 2007).

Planta de hábito zingiberoide, com 1,0 a 3,0 metros de
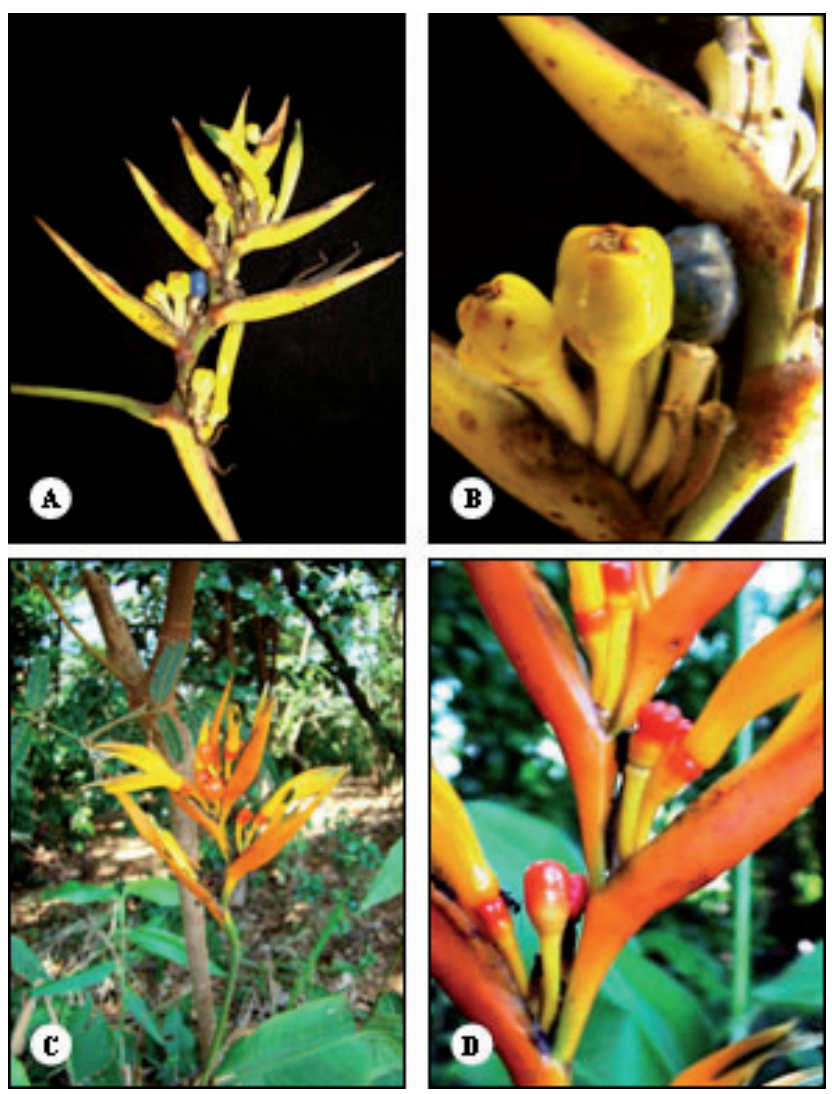

Figura 20. Heliconia hirsuta: a) cultivar Yellow Panamá; b) frutos maduros (azul) e imaturos (amarelos); c) cultivar Alicia; d) frutos em maturação.

Figure 20. Heliconia hirsuta: a) cultivar Yellow Panamá; b) mature fruits (blue) and immature (yellow); c) cultivar Alicia; d) fruits in maturation. 


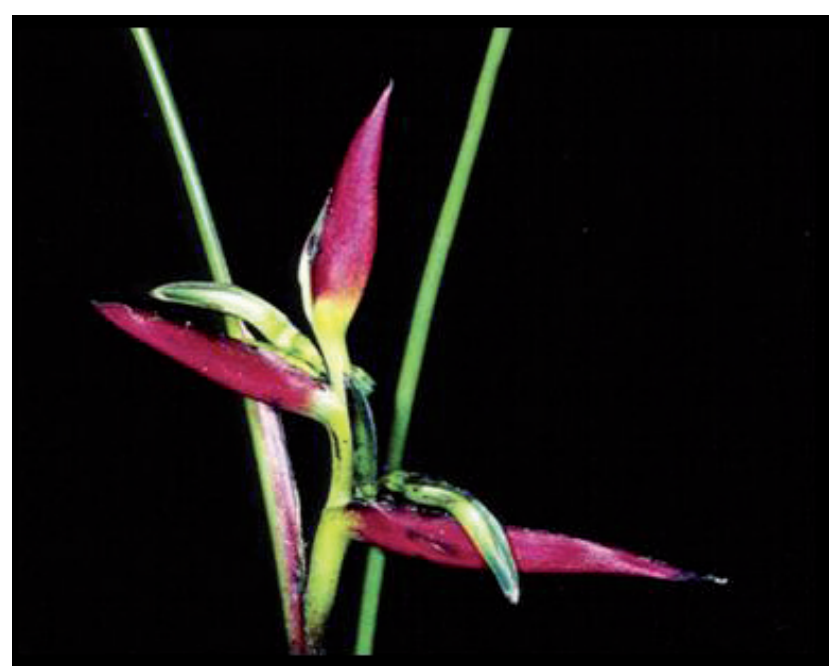

Figura 21. Heliconia schumanniana.

Figure 21. Heliconia schumanniana.

altura. Apresenta inflorescência ereta, de 6,0 a 20,0 $\mathrm{cm}$ de comprimento, com raque sinuosa, esverdeada, amarela ou alaranjada e glabra. As brácteas, em número de 2 a 10 por inflorescência, distribuem-se em um mesmo plano. Estão inseridas em um ângulo de 50 a $90^{\circ}$ em relação ao eixo da inflorescência, têm coloração esbranquiçada, amarela ou alaranjada na base e alaranjada para vermelho escuro distalmente. As flores são sigmoides, amarelas para laranjaamarelado (ANDERSSON, 1985).

Ocorre naturalmente em altitudes de 100 a 1.300 metros, no Estado do Acre, em florestas úmidas fechadas e pequenas clareiras, onde é mais vigorosa (ANDERSSON, 1985).

Distingue-se por suas pequenas flores sigmoides e se diferencia da H. apparicioi pelo formato e coloração das flores e por não apresentar cerosidade.

Espécie só conhecida na região de ocorrência natural.

\section{Subgênero Griggsia L. Anderss.}

\subsection{Sect. Pendulae (Griggs) W. J. Kress}

\subsubsection{H. chartaceae Lane ex Barreiros (Figura 22)}

Sinonímia: H. meeana Kress (CASTRO et al. 2007).

Planta de hábito musoide, com 2,0 a 3,0 metros de altura. As folhas são laceradas e com uma camada de cerosidade na face inferior. Apresenta inflorescência pendente, de 0,40 a 1,20 metros de comprimento, com raque sinuosa, contorcida, de coloração rósea ou vermelha e levemente pubérula, com pelos esbranquiçados. As brácteas, levemente pilosas, em número de 14 a 18 por inflorescência, distribuem-se em vários planos. Estão inseridas em um ângulo de 100 a $135^{\circ}$ em relação ao eixo da inflorescência e têm coloração vermelha ou rósea com margens vermelhas ou róseas e recobertas por fina camada cerosa esbranquiçada. As flores ocorrem em até 12 por bráctea e são esverdeadas (BARREIROS, 1972).

Ocorre naturalmente em altitudes de 100 a 800 metros, nos Estados do Amazonas e Pará, em locais semiabertos de florestas pluviais tropicais. Nessas regiões, recebe o nome popular de sororoca e tem florescimento de agosto a janeiro (BARREIROS, 1972).

É facilmente distinguida de outras espécies com inflorescências pendentes pela coloração rósea das brácteas com margens esverdeadas. Também as folhas são laceradas.

Espécie cultivada a pleno sol ou locais levemente sombreados, é utilizada tanto em jardins como flor de corte.

As principais cultivares comerciais são: Sexy Pink, Sexy Scarlet, Equador, Maroon e Meeana.
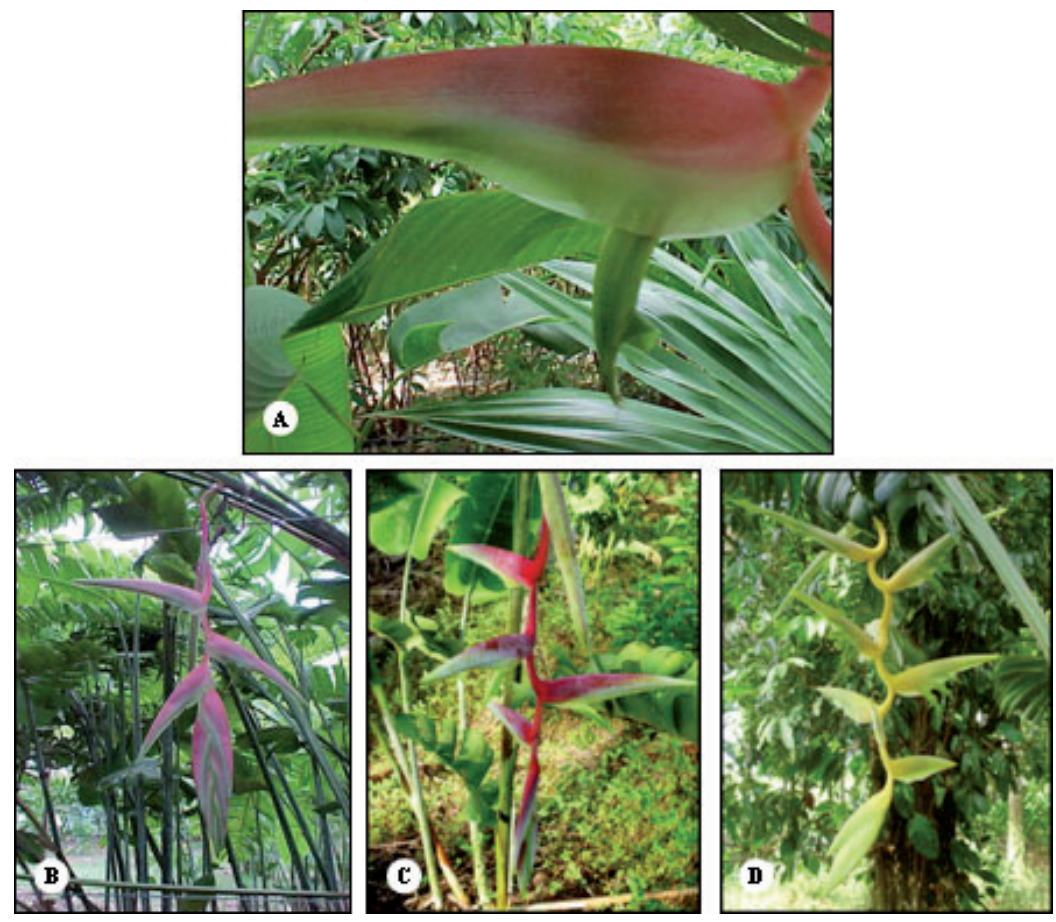

Figura 22. Heliconia chartaceae: a) detalhe de bráctea com flor exserta b) cultivar Sexy Pink; c) cultivar Sexy Scarlet; d) indivíduo em população natural na região de Altamira, PA, encontrado em alguns catálogos como cultivar Amazonita. Figure 22. Heliconia chartaceae: a) bract wit exsert flower b) ) cultivar Sexy Pink; c) cultivar Sexy Scarlet; d) plant in natural population in Altamira, PA, found in some catalogs as cultivar Amazonita. 
3.1.2 H. pendula Wawra (Figura 23).

Sinonímia: H. steyermarkii Aristeg. (CASTRO et al. 2007).

Planta de hábito musoide, com 2,5 a 4,5 metros de altura. Apresenta inflorescência pendente, de 45,0 a 95,0 cm de comprimento, com raque reta e levemente pubérula. As brácteas em número de 8 a 15 por inflorescência, são distribuídas em espiral. Estão inseridas em um ângulo de 30 a $70^{\circ}$ em relação ao eixo da inflorescência e têm coloração vermelha a vermelho-alaranjada. As flores são curvadas, de 10 a 15 por bráctea e brancas (BARREIROS, 1979).
Ocorre naturalmente em altitudes de 200 a 600 metros nos Estados da Bahia e do Espírito Santo, em margens de rios, em clareiras de florestas úmidas e mesmo na vegetação secundária de florestas (BARREIROS, 1979).

Facilmente reconhecida por suas inflorescências pendentes, com brácteas de coloração vermelho intenso e flores brancas.

É uma espécie sem cultivo comercial identificado e pode ser utilizada em jardins.

As principais cultivares comerciais são: Bright Red, Frosty, Red Waxy, Atlantica e Styermarkii.

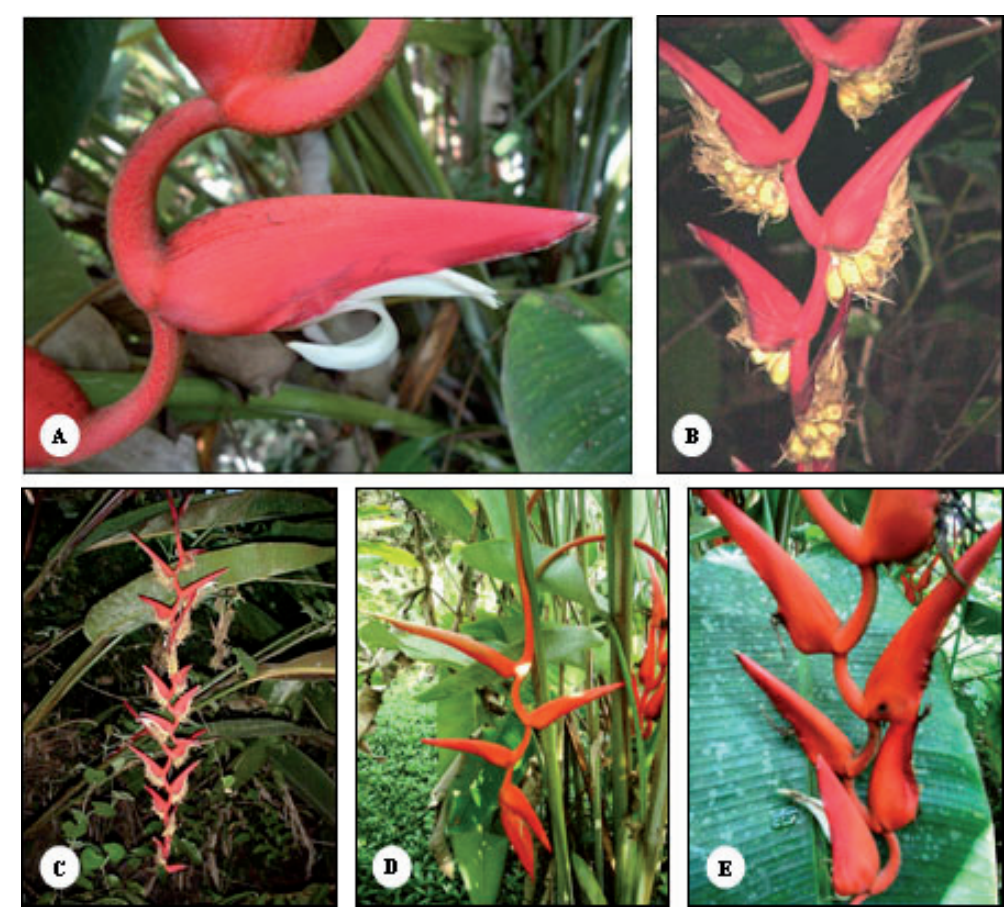

Figura 23. Heliconia pendula: a) pilosidade da raque e flor; b) inicio da frutificação; c) indivíduo em população natural; d) cultivar Red Waxy; e) cultivar Bright Red.

Figure 23. Heliconia pendula: a) rachis and flower hairiness; b) fructification begginig; c) plant in natural population; d) cultivar Red Waxy; e) cultivar Bright Red.

\subsection{Sect. Rostratae W. J. Kress}

\subsubsection{H. juruana Loes. (Figura 24).}

Sinonímia: H. triflora Barreiros (CASTRO et al. 2007).

Planta de hábito canoide, com 2,0 a 4,0 metros de altura. Apresenta inflorescência pendente, de até $46,0 \mathrm{~cm}$ de comprimento, com raque sinuosa e com cicatrizes, vermelha e pubérula. As brácteas caducas, em número de 10 a 30 por inflorescência, distribuem-se em diversos planos. Estão inseridas em um ângulo de 80 a $90^{\circ}$ em relação ao eixo da inflorescência e têm coloração vermelha nos dois terços basais e um terço amarelo-esverdeado no terço apical, são glabras ou esparsamente pubérulas. As flores são retas, de 3 a 4 por bráctea, de coloração branca ou amarelada em direção a base e verde em direção ao ápice (ANDERSSON, 1985).

Ocorre naturalmente em altitudes de 200 a 400 metros, nos Estados do Amazonas, Pará e Mato Grosso, em margens alagadas de rios e em áreas pantanosas de florestas úmidas.

É a menor de todas as espécies com inflorescências pendentes, sendo reconhecida por sua pequena inflorescência com brácteas caducas e poucas flores (ANDERSSON, 1985).

Espécie só conhecida na região de ocorrência natural.

\subsubsection{H. marginata (Griggs) Pittier (Figura 25).}

Planta de hábito musoide, com 2,0 a 3,0 metros de altura, com pseudocaule cinza-esverdeado e folhas na posição vertical. Apresenta inflorescência pendente, com até 40,0 $\mathrm{cm}$ de comprimento, com raque sinuosa, vermelha e pubérula. As brácteas, em número de 9 a 15 por inflorescência, distribuem-se em mais de um plano. Estão inseridas em um ângulo de 90 a $135^{\circ}$ em relação ao eixo da inflorescência e têm coloração vermelha com margens amarela ligeiramente esverdeada no ápice e amarela na face interna, ou totalmente amarela. As flores, ocorrem de 7 a 15 por bráctea e são amarelas (ANDERSSON, 1985).

Ocorre naturalmente em altitudes de 40 a 100 metros, nos Estados do Mato Grosso do Sul, Mato Grosso e Amazonas, em locais pantanosos e águas paradas, abertos ou protegidos. Nessas regiões, tem florescimento em julho e 


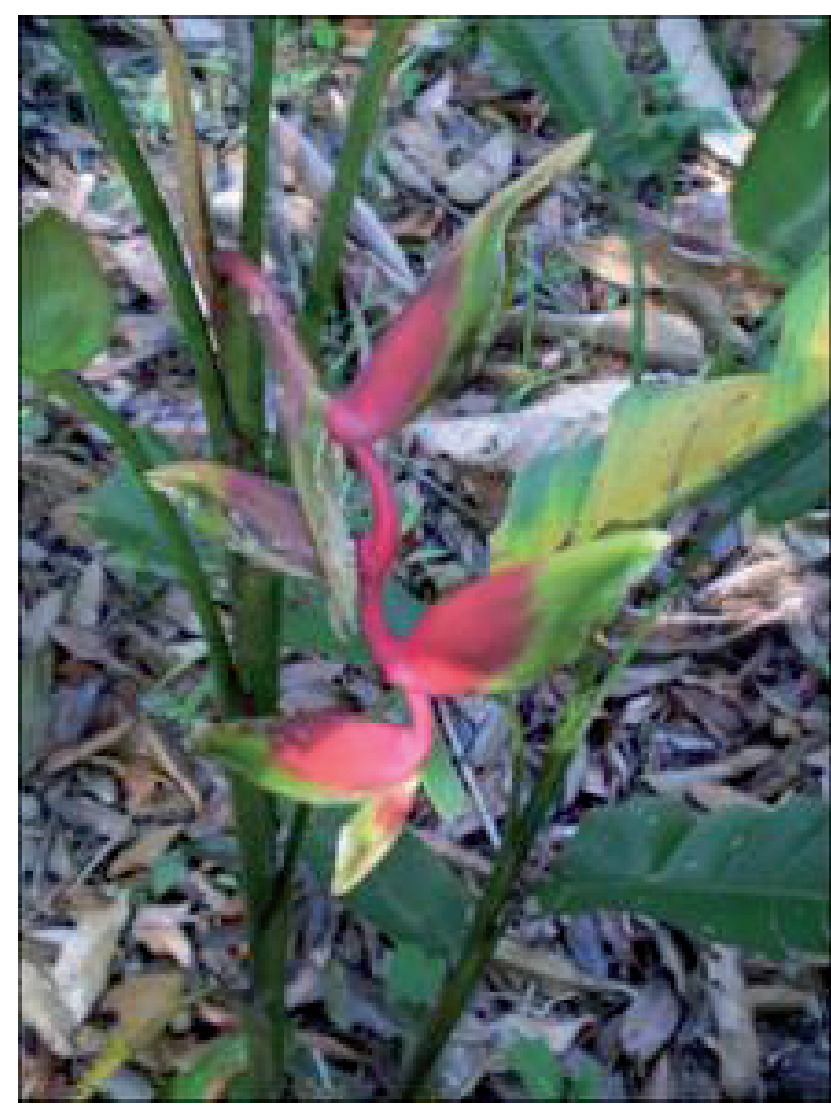

Figura 24. Heliconia juruana.

Figure 24. Heliconia juruana.

agosto (ANDERSSON, 1985).

É facilmente distinguida por ter hábito aquático e folhas dispostas verticalmente.

Cultivada a pleno sol, em locais encharcados, é preferencialmente usada como planta de jardim.

\subsubsection{H. rauliniana Barreiros (Figura 26).}

Planta de hábito musoide, com 2,0 a 3,0 metros de altura. Apresenta inflorescência considerada pendente, contorcida, de 28,0 a 30,0 cm de comprimento, com raque torcida e levemente pubérula. As brácteas, em número de 7 a 10 por inflorescência, distribuem-se em planos diversos. Estão inseridas em um ângulo de 15 a $100^{\circ}$ em relação ao eixo da inflorescência e têm coloração vermelha com margens amarelas com estrias verdes. As flores, ocorrem de 2 a 3 por bráctea, são brancas com ápices esverdeados (BARREIROS, 1974a).

Ocorre naturalmente em altitudes de 150 a 800 metros, nos Estados do Pará e Amazonas, em margens de rios, em florestas tropicais úmidas (BARREIROS, 1974a).

$\mathrm{Na}$ região de ocorrência natural, floresce de novembro a fevereiro.

Facilmente distinguida pela inflorescência contorcida.

Espécie de cultivo a pleno sol ou local levemente sombreado é indistintamente usada como planta de jardim e como flor de corte.

\subsubsection{H. rostrata R. \& P. (Figura 27).}

Sinonímia: $H$. poeppigiana Petersen (CASTRO et al. 2007).

Planta de hábito musoide, com 2,0 a 5,0 metros de al-

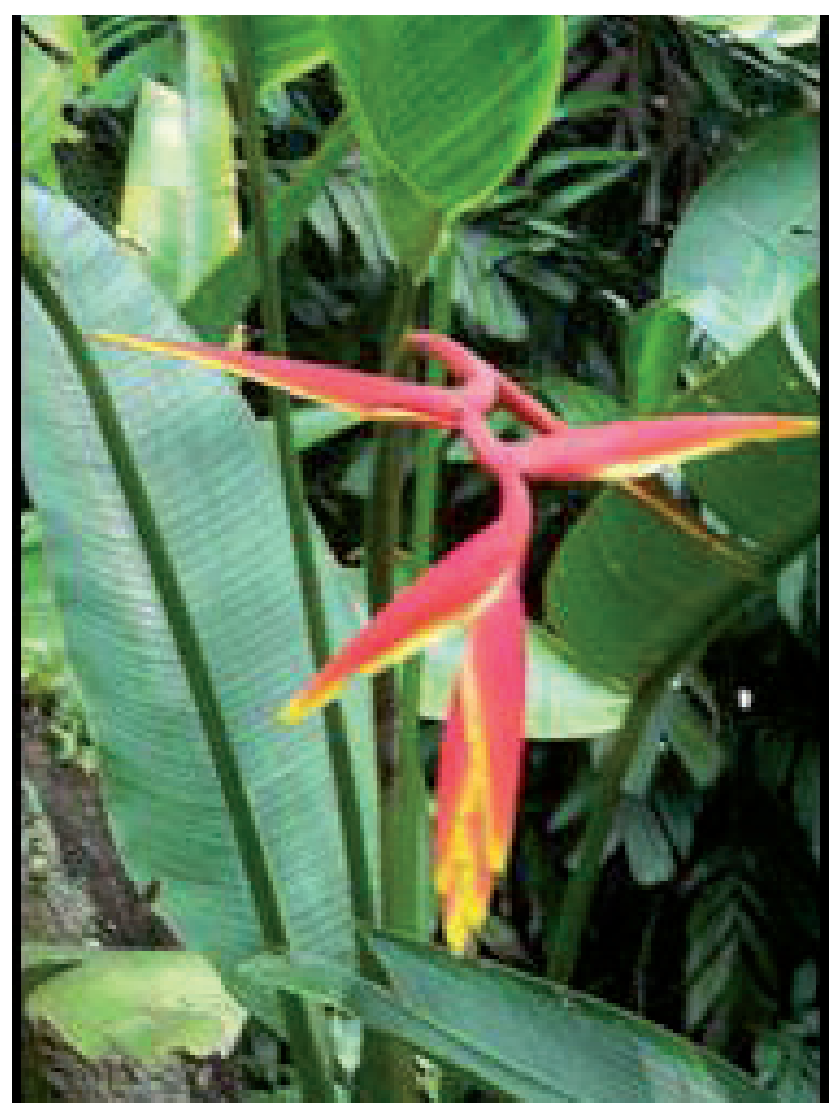

Figura 25. Heliconia marginata.

Figure 25. Heliconia marginata.

tura. Apresenta inflorescência pendente, com até $90,0 \mathrm{~cm}$ de comprimento, com raque sinuosa, vermelha e glabra ou pubérula. As brácteas, em número de 12 a 35 por inflorescência, distribuem-se em um mesmo plano, ou planos diversos. Estão inseridas em um ângulo de 90 a $130^{\circ} \mathrm{em}$ relação ao eixo da inflorescência e têm coloração vermelha com as margens amarelas ou amarelo-esverdeadas, verdes ou ainda mais escuras. As flores ocorrem de 2 a 5 por bráctea, são verde-amareladas e brancas em direção a base. Os frutos são azuis na maturidade e negros quando secos (ANDERSSON, 1985).

Ocorre naturalmente em altitudes de 300 a 800 metros, nos Estados do Amazonas e Rondônia, em florestas úmidas, planícies ou matas de galeria. Floresce o ano todo com pico entre setembro e março (ANDERSSON, 1985).

Distingue-se da $H$. standley por ser mais vigorosa e apresentar flores médias a grandes.

Espécie cultivada a pleno sol ou leve sombra é a mais difundida no país com uso em jardins, de forma isolada ou formando maciços florais. Tem também grande uso como flor de corte.

As principais cultivares comerciais são: Twirl, Giant, Dwarf, Misahualli, Pink Peru e Sun-kissed Orange.

\subsubsection{H. standleyi Macbr.}

Planta de hábito musoide, com 5,0 a 6,0 metros de altura. Apresenta inflorescência pendente, de até $55,0 \mathrm{~cm}$ de comprimento, com raque reta a sinuosa e levemente pubérula. As brácteas, em número de 11 a 25 por inflorescência, distribuem-se em planos diversos. Estão inseridas em um ângulo de 15 a $120^{\circ}$ em relação ao eixo da inflo- 

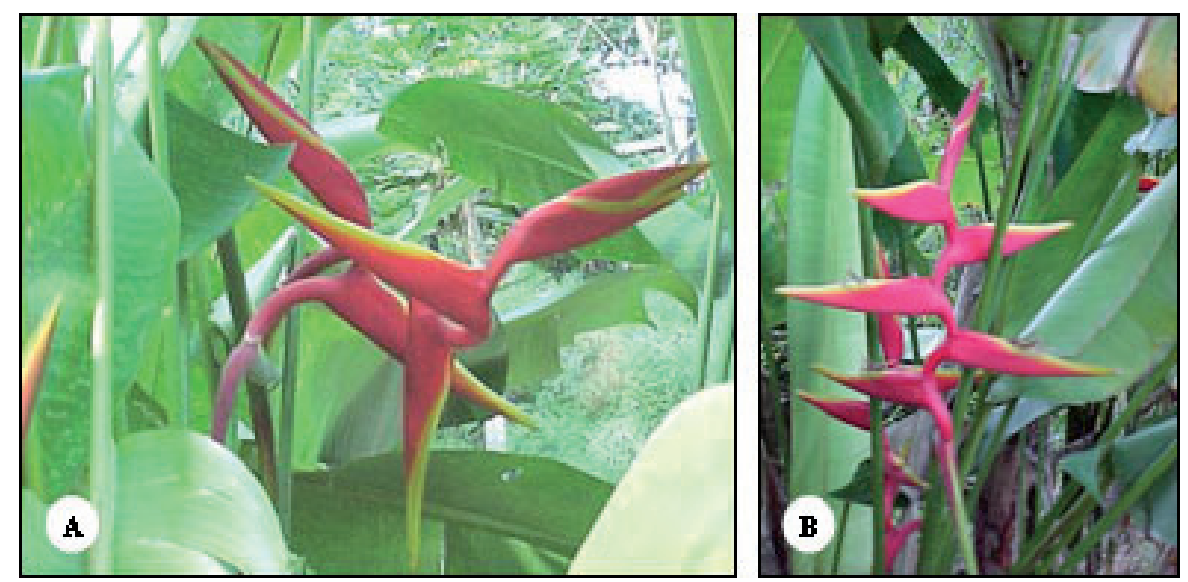

Figura 26. Heliconia rauliniana: a) raque retorcida; b) indivíduo em população natural.

Figure 26. Heliconia rauliniana: a) twisted rachis; b) plant in natural population.
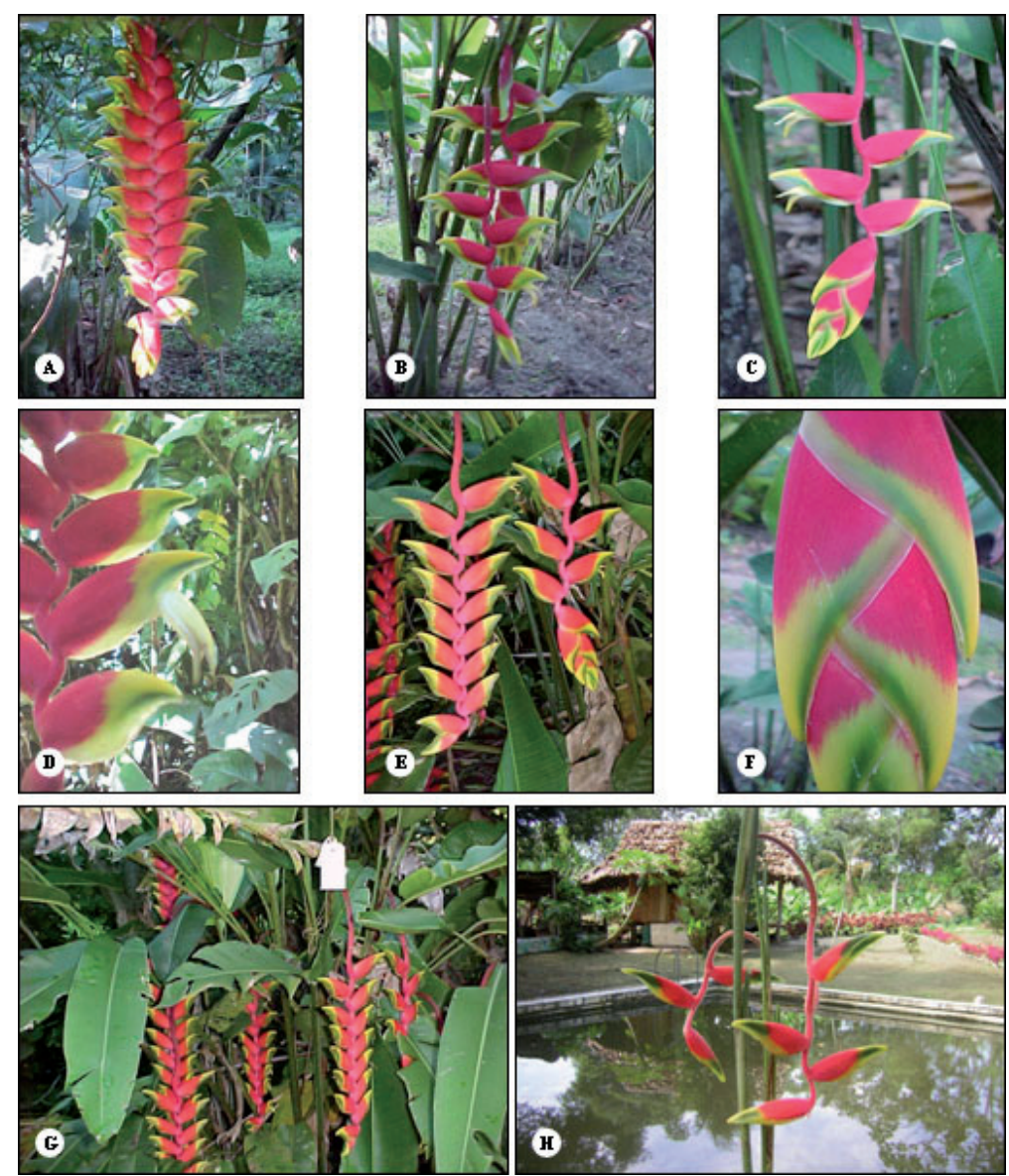

Figura 27. Heliconia rostrata: a-g) formas distintas; h) forma silvestre ocorrente na Amazônia, em cultivo em jardim de hotel da região.

Figure 27. Heliconia rostrata: a-g) distinct forms; $h$ ) wild form occurring in the Amazon, growing in the garden of the hotel.

rescência, têm coloração vermelha com margens amareloesverdeadas. As flores são retas e brancas em direção à base e verdes em direção ao ápice (MACBRIDE, 1931).

Ocorre naturalmente em altitudes de 300 a 800 metros nos Estados do Amazonas, Rondônia e Acre, em florestas úmidas, planícies ou matas de galeria (MACBRIDE, 1931).

Espécie só conhecida na região de ocorrência natural.

\section{LITERATURA CITADA}

ANDERSSON, L. Revision of Heliconia sect. Heliconia (Musaceae). Nordic Journal of Botany, v. 1 (6), p. 759786. 1981

ARISTEGUIETA, L. El Genero Heliconia em Venezuela. 
Instituto Botanico. Dirección de Recursos Naturales REnovables. Ministerio de Agricultura y Cria. Caracas, 1961. $1-21 \mathrm{p}$.

BARREIROS, H. S. Notas sobre Heliconia linneana Lane In: HERB. Revista Brasileira de Biologia, São Calos, v.30, n.4, p.571-537, 1970.

BARREIROS, H. S. Lista de espécies de Heliconia L. (Musaceae), de inflorescência pêndula. Atas da Sociedade de Biologia do Rio de Janeiro, Rio de Janeiro, v.15, n.2, p. 55-58, 1971a.

BARREIROS, H. S. Novos aspectos morfológicos e ecológicos de Heliconia metallica (P. e L.) Hook, relacionados com o escapo paramorfo. Revista Brasileira de Biologia, São Carlos, v.31, n.4, p.89-492, 1971 b.

BARREIROS, H. S. Heliconia nova brasiliana et varietas. Morfologia e ecologia - dispersão e polinização (Heliconiaceae (End.) Nakai). Revista Brasileira de Biologia, São Carlos, v.32, n.2, p.205-208, 1972.

BARREIROS, H. S. Espécies críticas de Heliconia (Heliconaceae). - III. Com duas espécies brasileiras sendo uma nova. Bradea, Rio de Janeiro, v.1, n.46, p.459-464. 1974a.

BARREIROS, H. S. Heliconia nova da Venezuela com flores aquáticas (Heliconaceae). Bradea, Rio de Janeiro, v.1, n. 45, p.453-457, 1974 b.

BARREIROS, H. S. Novas localidades de ocorrência de Heliconia L. - I (Heliconaceae). Bradea, Rio de Janeiro, v. 1, n. 44 , p.447-425, 1974 c.

BARREIROS, H.S. Heliconiae novae Americanae (Heliconiaceae). Rodriguesia, Rio de Janeiro, v.28, n.41, p. 128-136, 1976.

BARREIROS, H.S. Heliconias com inflorescência pendula (Heliconiaceae). Rodriguesia, Rio de Janeiro, v.31, n.50, p. 259-268, 1979.

BELL, A. D.; TOMLINSON, P. D. Adaptative architecture in rhizomatous plants. Botanical Journal of the Linnean Society, London, v.80, p.125-160, 1980.

BURLE-MARX, R. Heliconiae novae brasiliensis II. Sobre uma nova espécie de Heliconia L. (Musaceae). Bradea, Rio de Janeiro v.1, n. 38, p.379-382, 1974.

CASTRO, C.E.F. \& GRAZIANO, T.T. Espécies do Gênero Heliconia (Heliconiaceae) no Brasil. Revista Brasileira de Horticultura Ornamental, Campinas, v.3, n.2, p.15-28, 1997.

CASTRO, C. E. F. ; GONÇALVES, C. ; MAY, A. . Atualização da nomenclatura de espécies do gênero Heliconia
(Heliconiaceae). Revista Brasileira de Horticultura Ornamental, Campinas, v. 13, p. 38-62, 2007.

CRONQUIST, A. An integrated system of classification of flowering plants. Columbia University Press, New York, 1981.

KRESS, J. The diversity and distribution of Heliconia (Heliconiaceae) in Brasil. Acta Botanica Brasilica, São Paulo, v.4, n.1, p.159-157, 1990.

MACBRIDE, J. F. Spermatophytes mostly Peruvian. III. Boletim do Museu Nacional 11(1): 3-35. 1931.

MELLO FILHO, L. E. O gênero Heliconia na flora fluminensis de frei José Mariano da Conceição Vellozo. Revista Brasileira de Biologia, São Carlos, v.35, p. 331-337, 1975.

MELLO FILHO, L.E. Heliconiae novae Brasiliensis III. Bradea, Rio de Janeiro, v.2, n.15, p.91-94, 1976.

MELlO FILHO, L.E. \& SANTOS, E. Heliconiae Novae Brasiliensis IV. Bradea, Rio de Janeiro, v.11, n.16, p.95104, 1976.

MELLO FILHO, L.E. \& SANTOS, E. Heliconiae Novae Brasiliensis V. Bot. Mus. Nac. v.43, p.1-8, 1977.

MELlO FILHO, L.E \& SANTOS, E. Heliconiae Novae Brasiliensis VII. Bradea, Rio de Janeiro, v.41, n.3, p.370372, 1983.

MELLO FILHO, L.E. \& SANTOS, E. Heliconiae Novae Brasiliensis VIII. Bradea, Rio de Janeiro, v.44, n.4, p.350352, 1987a.

MELLO FILHO, L.E. \& SANTOS, E. O gênero Heliconia na subregião fluminense: O "Status" de suas espécies endêmicas (1). Bradea, Rio de Janeiro, v.44, n.4, p.353-358, $1987 b$.

NAKAI, T. Notulae ad plantas Asiae Orientalis XVI. Japanese Journal of Botany, Japão, v.17, n.4, p.189-203, 1941.

SANTOS, E. Revisão das espécies de gênero Heliconia L. (Musaceae) exontâneas na região fluminense. Rodriguésia, Rio de Janeiro, v. 45, p. 99-221, 1978.

TOMLINSON, P. B. An anatomical approach to the classification of the Musaceae. Botanical Journal of the Linnean Society, London, v.55, n.364, p.779-809, 1959.

TOMLINSON, P.B. Phylogeny of the Scitamineae - morphological and anatomical considerations. Evolution, Miami, v.16, p.192-213, 1962. 